\title{
OS BOIS DE CARNE E OSSO, AS VACAS SINTÉTICAS E O PIXO URBANO: QUANDO A ESTÉTICA DE RUA AFRONTA A ÉTICA DA “OBRA DE ARTE” NA CIDADE DE BELÉM (PA).
}

\author{
Flávio Leonel Abreu da Silveira ${ }^{1}$ \\ Petronio Medeiros Lima Filho ${ }^{2}$
}

\section{Das vacas e bois: do colorido à putrescência na urbe ${ }^{3}$}

Neste artigo buscamos compreender os dilemas em torno da ação de uma $\operatorname{artista~}^{4}$ que pixou ${ }^{5}$ a palavra "NAUFRÁGIO" no corpo sintético de uma das vacas da CowParade Belém 400 anos, evento internacional de arte na rua ${ }^{6}$ que aconteceu na capital do estado do Pará, no ano de 2016. Para tanto, partimos do princípio de que a pixação enquanto uma agência de significativa inserção ético-estética conectou dois episódios de grande impacto no contexto paraense, mas que aparentemente não tinham nenhuma ligação direta entre si, quais sejam: 1. O episódio envolvendo "bovinos" chamado CowParade, no qual 50 vacas de fibra de vidro foram customizadas por

\footnotetext{
${ }^{1}$ Universidade Federal do Pará, Brasil. Email: flabreu@ufpa.br ORCID id: https://orcid.org/0000-0001-9421-5966

${ }^{2}$ Instituto Nacional de Colonização e Reforma Agrária - INCRA, Brasil. Email: petronio.mlf@gmail.com ORCID id: https://orcid.org/0000-0002-1096-5135

${ }^{3}$ Agradecemos a leitura de Andréa Osório, mas ressaltamos que todo e qualquer equívoco presente no artigo é de nossa absoluta responsabilidade.

${ }^{4} \mathrm{Na}$ verdade, a sua intervenção se insere num conjunto de outras manifestações realizadas por um grupo de artistas locais, portanto se trata de uma ação coletiva inserida numa proposta estética de crítica social no mundo urbano contemporâneo amazônico, mais especificamente nas cidades de Barcarena e Belém. As "ações", como se referiu uma das integrantes do grupo, giravam em torno dos problemas relacionados à extração de bauxita e alumínio, bem como aos desdobramentos do naufrágio que vitimou milhares de bovinos na cidade de Barcarena, situada nas proximidades da capital do Estado. Por tratar-se de um ilícito manteremos os nomes das artistas em anonimato, ou quando nos utilizarmos da fala de uma das integrantes do grupo com quem conversamos mudaremos o seu nome. Por outro lado, é preciso destacar que existem coletivos de mulheres e, mesmo, artistas independentes, que atuam no cenário da street art (pixo, graffiti) no contexto belenense, como mostra o trabalho de Maciel (2019).

5 Optamos por utilizar a expressão "pixo", e não picho, por ser a forma corrente entre a maioria dos protagonistas da street art no contexto de Belém (PA). A utilização do termo, a partir de uma linguagem de rua, refere-se as práticas que realizam na cidade, visto que nas paredes e muros os artistas escrevem "pixação" ao invés de pichação, como exige a norma culta.

${ }^{6}$ Dizer que a CowParade é um evento de arte na rua não significa dizer que seja street art, no sentido de um tipo de arte que emana das relações/ações/intervenções plurais de artistas situados fora de certo eixo da arte com o mundo urbano, como é o caso do pixo e de manifestações do graffiti que escapam aos espaços das galerias. Portanto, trata-se de uma estética "marginal", de caráter subterrâneo que floresce simbólicas na cidade, e cuja crítica social revela manifestações juvenis que se traduzem em formas éticoestéticas de culturas de rua. Para tanto, ver Pereira (2010); Pinheiro (2011); Diógenes e Chagas (2016), Diógenes, Ramos e Eckert (2016).
}

Iluminuras, Porto Alegre, v. 21, n. 54, p. 527-568, setembro, 2020. 
artistas da cena de arte local e, a partir daí, transformadas em obras de arte espalhadas por diversos pontos da cidade de Belém; 2. O naufrágio de um navio carregado de bois vivos no porto de Vila do Conde, município de Barcarena, localizado a poucos quilômetros de Belém, que matou milhares de bovinos (resultando em 2.450 toneladas de carcaças), e derramou no rio cerca de 700 mil litros de óleo que estavam na embarcação causando um grande desastre socioambiental com repercussões econômicas sérias para as comunidades ribeirinhas, já que os resíduos do desastre (carcaças e óleo) confundem as ordens do limpo e do sujo, do lixo e do asseio nas paisagens, impossibilitando o curso normal da vida no mundo urbano ${ }^{7}$.

$\mathrm{O}$ artigo em questão procura estabelecer algumas reflexões sobre as distintas interpretações que surgiram sobre o referido pixo. Neste caso, à ação de caráter político impetrada pela artista na superfície corporal de uma vaca sintética da exposição CowParade. Diversas leituras acerca do seu ato foram veiculadas pela mídia televisiva local, bem como na internet, associando o pixo enquanto uma intervenção urbana a um ato de desrespeito associado a ideia de "vandalismo" 8 e, de acordo com a interpretação televisiva, como uma ação que nada tinha a ver com a expressão artística, aviltando, assim, a intencionalidade estética do autor da "obra" de arte urbana, desqualificando a arte de rua na medida em que parece associar a pixação à noção de lixo estético nas artes.

\section{Um sobrevoo sobre a CowParade, ou como as vacas suecas reverberam nas de Belém}

Uma primeira questão antes de pontuarmos alguns aspectos sobre o evento CowParade, envolve uma rápida, mas necessária, reflexão sobre o lugar do gado bovino na expansão do imperialismo europeu no Mundus Novus (Crosby, 1993), ou seja, de como a introdução deste tipo de animal acarretou a transformação paulatina das

\footnotetext{
${ }^{7}$ Ainda que neste artigo não abordemos em profundidade, um terceiro elemento também subjaz a esse debate, trata-se da extração do alumínio (Monteiro, 2007; Pedrosa Neto; Silveira, 2018) e da bauxita no município de Barcarena, cujo enorme impacto socioambiental atinge ecossistemas praticados por coletivos humanos (tradicionais ou não) com enorme prejuízo à saúde ambiental e das pessoas, reconfigurando os lugares em paisagens catastróficas (Cloarec, 1989), pois o processo produz poluições de diferentes ordens, assim como rejeitos oriundos da dinâmica físico-química de extração/beneficiamento dos minérios.

${ }^{8}$ As imagens do vandalismo se referem à ideia de degradação/destruição ora da propriedade privada, ora de um patrimônio comum da cidade (histórico ou não). De qualquer forma trata-se de uma ação considerada ilegal por danificar o patrimônio alheio de caráter privativo ou comum, que descaracterizaria o mesmo a partir de uma prática que, além disso, não seria considerada arte. Sobre o pixo incorrem muitos juízos de gosto e de valores que se colocam, não raro, como de classe. Ver Bourdieu (1983); Pereira (2010).
} 
paisagens americanas - com a conformação de civilizações do gado/couro ${ }^{9}$ possuidoras de diferentes figurações em diversos contextos americanos envolvendo taurofilias/fobias, desdobradas em tauromaquias de muitas ordens, portanto, associadas a consolidação da conquista e vinculadas as formas de colonialismos que oprimiram humanos e não-humanos locais pela expansão da pecuária em seus territórios originários $^{10}$, engendrando formas múltiplas de mestiçagens socioculturais. O que nos parece evidente é que a pata do gado também trouxe sementes invasoras que ajudaram a transformar a ecologia americana (Rappaport, 1992). Neste sentido, a presença bovina, enquanto espécie exótica, não é inócua e nem menos política quanto às feições imperialistas de construção de espaços friccionados de tensões culturais, sempre mediadas pelo terror (Taussig, 1993). Dito isso, seguimos com a nossa reflexão indicando como as vacas sintéticas ${ }^{11}$, no nosso ponto de vista, ainda que re-significadas, colonizam as artes alheias.

Com estas questões em mente sigamos conhecendo mais sobre a origem deste evento - e sobre a maneira como se realizou na região amazônica, na cidade de Belém do Pará. De acordo com Pozzobon (2011), a origem e o desenvolvimento do evento Cowparade, bem como as relações com a empresa TopTrends que o realiza no Brasil são expressas desta maneira:

\begin{abstract}
Em dezembro de 1996, o pai do artista plástico Pascal Knapp, Walter Knapp pediu ao filho para projetar uma vaca em tamanho natural, para uma tradicional exposição em Zurique, Suíça. Estas esculturas foram distribuídas para artistas locais as pintarem e serem colocadas à mostra na exposição. Knapp apresentou os atuais três modelos de esculturas de vacas que fazem parte da mostra: uma deitada, um pastando e outro de pé. Foram ao todo 450 vacas que integraram esta primeira exposição, sempre seguindo os três modelos originais: uma deitada, um pastando e outro de pé. A exposição chamou a atenção de Jerry Elbaum, que comprou os direitos autorais das esculturas e de sua exibição em vias públicas fundando assim a CowParade Holding Inc. No Brasil, a empresa responsável pelos direitos da CowParade é a TopTrends. (...) A TopTrends foi criada em março de 2004, tem sua sede em São Paulo e desde 2005 tem os direitos da CowParade Holding Inc. Composta por Catherine Duvgnau e Ester Krivink, a empresa presta consultoria para o evento CowParade e cuida de todos contatos publicitários das edições pelo Brasil. A TopTrends banca de $10 \%$ a $15 \%$ das vacas, as outras são "adotadas" por patrocinadores do evento. A primeira exibição com o caráter e a denominação da CowParade aconteceu em 1999 na cidade de Chicago e, desde então já passou por mais de 50 cidades de diferentes países do mundo. (Pozzobon, 2011: 2746-2747)
\end{abstract}

\footnotetext{
${ }^{9}$ Para o contexto das Missões sul-riograndenses ver Silveira (2004).

${ }^{10}$ No que se refere ao contexto amazônico e, mais especificamente ao de Rondônia, ver Vander Velden (2011).

${ }^{11}$ Deixamos claro que neste artigo faremos referência apenas a algumas vacas sintéticas que fizeram parte da exposição da CowParade.
} 
Assim, a origem da exposição que alavancou a CowParade se deu entre artistas suíços, num contexto onde a vaca possui significados específicos na vida dos habitantes daquele lugar, no entanto, comprados os direitos das esculturas o evento tornou-se global, sendo realizado em inúmeros países até aportar na Amazônia Brasileira. Aqui como nos outros lugares em que foi realizada a intervenção, trouxe para os corpos das vacas - tela tridimensional - elementos que dialogam com a cultura local.

A fim de compreendermos tal cenário a nossa incursão ao universo do CowParade teve início a partir de uma visita ao site oficial do evento ${ }^{12}$, onde as suas dimensões e abrangências no contexto nacional se delinearam, ficando evidente que as suas proporções no contexto brasileiro são bastante significativas quando se pensa no número de pessoas envolvidas e nos montantes financeiros acionados por ele: são 14 anos de CowParade no país, com 13 edições já realizadas envolvendo 700 artistas, com 20.2 milhões de reais em patrocínio, mais de 15 milhões de reais de mídia espontânea e, segundo os dados oficiais, aproximadamente 20 milhões de pessoas já se depararam com uma das exposições no Brasil ${ }^{13}$. Ainda, segundo dados do mesmo site o evento já foi realizado ininterruptamente ao longo de 22 anos em várias cidades localizadas em diversos continentes e países pelo mundo, considerando-se o início no ano de 1998 na cidade de Zurique na Suíça. A sequência de cidades até o ano de 2019 (ano de encerramento desta pesquisa) onde o evento ocorreu aparece abaixo, conforme tabela:

\begin{tabular}{|c|c|c|}
\hline $\mathrm{N}^{\mathrm{o}}$ & ANO & COWPARADE PELO MUNDO - CIDADES/PAÍSES \\
\hline 1 & 1998 & Zurique (Suíça) \\
\hline 2 & 1999 & Chicago (EUA) \\
\hline 3 & 2000 & Nova Iorque, Stanford, West Orange (EUA) \\
\hline 4 & 2001 & Kansas City e Houston (EUA), Sydney (Austrália) \\
\hline $5 \mathrm{a}$ & 2002 & Londres (Reino Unido), Ventspils (Letônia), Portland e Las Vegas (EUA) \\
\hline $5 \mathrm{~b}$ & $2002 / 2003$ & San Antônio (EUA) e Auckland (Nova Zelândia) \\
\hline 6 & 2003 & $\begin{array}{l}\text { Atlanta e West Hartford (EUA), Bruxelas (Bélgica), Dublin (Irlanda), Ilha de Man } \\
\text { (Reino Unido), Tóquio (Japão) }\end{array}$ \\
\hline $7 \mathrm{a}$ & 2004 & $\begin{array}{l}\text { Harrisburgo (EUA), Praga (República Tcheca), Estocolmo (Suécia), Manchester } \\
\text { (Reino Unido), Durban (África do Sul) }\end{array}$ \\
\hline $7 \mathrm{~b}$ & $2004 / 2005$ & Cape Town (África do Sul) \\
\hline $8 \mathrm{a}$ & 2005 & $\begin{array}{l}\text { Johanesburgo (África do Sul), Varsóvia (Polônia), Barcelona (Espanha), Monte } \\
\text { Carlo (Itália), Bratislava (Eslováquia), Bucareste (Romênia), Genebra (Suíça), São } \\
\text { Paulo (Brasil), Moscou (Russia) }\end{array}$ \\
\hline $8 \mathrm{~b}$ & $2005 / 2006$ & Florença (Itália), Cidade do México (México) \\
\hline 9 & 2006 & $\begin{array}{l}\text { Buenos Aires (Argentina), Wisconsin, Boston, Denver (EUA), Belo Horizonte e } \\
\text { Curitiba (Brasil), Lisboa (Portugal), Atenas (Grécia), Edimburgo (Reino Unido), } \\
\text { Tóquio (Japão), Telemark (Noruega), Budapeste (Hungria), Paris (França) }\end{array}$ \\
\hline 10 & 2007 & $\begin{array}{l}\text { Milão (Itália), Vigo (Espanha), Marselha (França), Istambul (Turquia), } \\
\text { Copenhague (Dinamarca), West Hartford (EUA), Rio de Janeiro (Brasil), } \\
\text { Guadalajara (México) }\end{array}$ \\
\hline
\end{tabular}

\footnotetext{
${ }^{12}$ Ver em: www.cowparede.com

${ }^{13}$ Ver: https://www.cowparade.com.br/numeros-no-brasil)
} 


\begin{tabular}{|l|l|l|}
\hline 11 & 2008 & São José (Costa Rica), Tijuana e León (México), Madri (Espanha), Tóquio (Japão) \\
\hline 12 & 2009 & La Jolla (EUA), Lima (Peru), Taipei e Hong Kong (China) \\
\hline 13 & 2010 & $\begin{array}{l}\text { Xiamen (China), Margaret River (Austrália), Roma (Itália), Tunis (Tunísia), São } \\
\text { Paulo (Brasil), Bordeaux (França) }\end{array}$ \\
\hline 14 & 2011 & $\begin{array}{l}\text { Austin (EUA), Florianópolis (aconteceu também em Joinville e Balneário } \\
\text { Camboriú) (Brasil) }\end{array}$ \\
\hline 15 & 2012 & Rio de Janeiro e Goiânia (Brasil), Toulouse (França), Carolina do Norte (EUA) \\
\hline 16 & 2013 & $\begin{array}{l}\text { Irlanda do Norte (Reino Unido), Hong Kong (China), Valenciennes (França), } \\
\text { Ventspils (Letônia) }\end{array}$ \\
\hline 17 & 2014 & Detroit (EUA), Shanghai (China) \\
\hline 18 & 2015 & Nizeko (Japão), Cartagena (Colômbia), Paris, Deauville e Cannes (França) \\
\hline 19 & 2016 & Surrey Hill (Reino Unido), Perth (Austrália), Belém (Brasil) \\
\hline 20 & 2017 & San Luis Obispo (EUA), São Paulo e Recife (Brasil). \\
\hline 21 & 2018 & Fortaleza (Brasil) \\
\hline 22 & 2019 & Salvador (Brasil) \\
\hline
\end{tabular}

O Brasil figura neste cenário há bastante tempo. Para conhecermos melhor as dinâmicas ético-estéticas mobilizadas pelas edições da CowParade no país, e portanto os desdobramentos sociopolíticos deste tipo de intervenção urbana nas cidades brasileiras, cruzamos os dados oficiais presentes na página do referido evento com algumas informações disponíveis em jornais, sites e outras fontes de circulação nacional e, a partir daí chegamos às seguintes informações: 1) sobre a sequência de realização do CowParade no Brasil percebemos que ao longo de 14 anos, entre 2005 e 2019, foram realizadas 16 edições do evento em 13 diferentes cidades brasileiras; 2) acerca dos períodos da realização do CowParade no Brasil, os dados indicam que ocorreram em três períodos distintos: a primeira edição do evento aconteceu em 2005 na cidade de São Paulo. A partir daí foi realizado consecutivamente nos dois anos seguintes: 2006 nas cidades de Belo Horizonte e Curitiba e, em 2007 na cidade do Rio de Janeiro $\left(1^{\circ}\right.$ período de 2005-7). Em 2010 o CowParade voltou a ser realizado na cidade de São Paulo, e no mesmo ano se realizou pela primeira vez em Porto Alegre. No ano seguinte, 2011, foi realizado em três cidades de Santa Catarina (Joinville, Balneário Camboriú e Florianópolis), e novamente no Rio de Janeiro. No ano de 2012 aconteceu na cidade de Goiânia ( $2^{\circ}$ período de 2010-12). Em 2016 a exposição veio para a cidade de Belém e, no ano seguinte, 2017, foi novamente realizado em São Paulo e pela primeira vez na cidade de Recife; 2018, na cidade de Fortaleza e 2019 em Salvador ( $3^{\circ}$ período de 2016$19)^{14}$.

\footnotetext{
${ }^{14}$ Assim, entre os anos de 2005 a 2019, nas 16 edições realizadas no Brasil o CowParade chegou em todas as regiões brasileiras Norte, Nordeste, Sul, Centro-Oeste, sendo ao longo desse tempo predominantemente realizadas na região Sudeste: Além de outras cidades dessa região, São Paulo recebeu três edições $(2005,2010,2017)$ e Rio de Janeiro duas $(2007,2011)$ do evento.
} 
O que fica claro em nosso levantamento quanto a realização do CowParade no Brasil, especialmente quando se pensa na sua circulação pelas regiões brasileiras, é que o acontecimento de caráter globalizante segue um padrão que, de certa forma, se repete em outros países. As primeiras edições acontecem nas cidades maiores (geralmente, capitais do tipo grandes metrópoles ou megalópoles), naquelas mais populosas ${ }^{15} \mathrm{e} / \mathrm{ou}$ mais importantes econômica e/ou politicamente, e depois se espalham para outras cidades e regiões do país, de maneira a se interiorizarem nos contextos em que se inserem como eventos culturais.

Entretanto, quando se pensa o CowParade em escala global, considerando as suas relações com as cidades ao longo do tempo, é possível vislumbrar o que parece ser uma certa decadência do evento no mundo contemporâneo, como indicaremos adiante. É preciso evidenciar que o CowParade se realiza em cidades por todo o mundo, é sempre uma relação/intervenção nas cidades. Ao logo dos 22 anos de realização ininterrupta e, exceto nos seus dois primeiros anos 1998 e 1999, e nos seus dois últimos 2018 e 2019 de realização, todas as edições ocorreram em cada ano simultaneamente em várias cidades de diferentes países, o que confere ao CowParade uma escala global de atuação, mas com predominância dos eventos acontecendo em cidades e países ocidentais.

No site oficial do evento está explícito um convite aos "[i]nteressados em organizar o Cowparade", ou ainda, àquele que deseja ser um "Anfitrião CowParede". E convoca: "Leve o maior evento de arte pública do mundo para sua cidade natal". Trata-se, portanto, de um feito que é literalmente comprado e levado às cidades.

O fato de que somente nos dois primeiros anos (1998 em Zurique, Suíça, e em 1999 na cidade de Chicago - EUA) e nos dois últimos (até o fechamento desta pesquisa 2018 em Fortaleza e 2019 em Salvador, ambas no Brasil), o CowParade ter sido realizado em apenas uma única cidade, parece indicar uma espécie de decadência na realização do evento, considerando que entre os anos 2000 a 2017 o CowParade, em cada um destes anos, sempre ocorreu simultaneamente em pelo menos duas cidades, sendo na maioria das vezes realizado em três ou mais delas no mesmo ano.

Apenas para citar um exemplo do que parece ter sido o ápice da trajetória do CowParade, no ano de 2006, este evento aconteceu nada menos do que em 13 cidades, localizadas em 9 diferentes países, espalhados por 3 continentes (América, Europa e

\footnotetext{
15 Todavia, não nos parece que este seja um motivo para a relativa demora na realização do evento na capital paraense, pois a região metropolitana de Belém é uma das mais populosas do país, com mais de dois milhões e meio de habitantes.
} 
Ásia). Neste contexto, o retorno da realização do CowParade em apenas uma única cidade por ano, parece indicar o fechamento de um ciclo de 22 anos, e talvez um certo esgotamento no encanto pelos simulacros de vacas e/ou um limite para a forma e o conteúdo deste tipo evento, pois duas décadas parecem ter feito a "parada das vacas" se tornar cada vez mais desinteressante para sociedades consumistas sempre ávidas pelo novo (Baudrillard, 1985), mas somente o tempo dirá.

\title{
3. As vacas de fibra de vidro na cidade de Belém e o apelo kitsch da estética urbana
}

Em 20 de agosto de 2016 o evento internacional chamado CowParade aportou na cidade de Belém, estado do Pará. No site oficial da proposta os organizadores definem o Cowparade como "o maior e mais bem sucedido evento de arte pública no mundo" ${ }^{16}$. Na sua versão paraense chegou às ruas da capital do Estado com o nome de “Cowparade Belém 400 anos”. O jornal O Liberal ${ }^{17}$ anunciou entusiasticamente o evento na capa e em página inteira da sessão Magazine do dia 19 de agosto de 2016, com a seguinte manchete: “As Vacas da Solidariedade”, com o subtítulo: "Belém será tomada, a partir de amanhã, pela arte das vacas da Cowparade que ajudará projetos sociais". A matéria assim se expressava:

\begin{abstract}
Amanhã, a capital paraense se tornará palco do maior evento de arte a céu aberto do mundo, a CowParade Belém 400 anos. O rebanho colorido, pintado a mão por 44 artistas locais, ficará em exposição nos mais diversos pontos da cidade até o dia 20 de setembro. Depois, as obras serão leiloadas e a verba arrecadada será revertida para projetos de responsabilidade social. A festa de lançamento, somente para convidados, será realizada hoje, às $19 \mathrm{~h} 30$, no Parque da Residência. No local, eles terão a oportunidade de conhecer as 50 vacas em primeira mão antes da mostra se espalhar pela cidade. As 50 peças ficarão expostas em locais estratégicos de Belém como praças, shopping centers, pontos turísticos, farmácias, órgãos públicos, aeroporto e rodoviária. Locais populares como a Praça Batista Campos, o Ver-oPeso, Portal da Amazônia, Parque da Residência, Mangal das Garças e Estação das Docas, também receberão as vaquinhas coloridas. (Jornal O Liberal, 19 de agosto de 2016) (grifo nosso)
\end{abstract}

O jornal traz o anúncio da chegada de um "rebanho colorido" de vacas sintéticas, que conforme descrito tomou de fato a cidade de Belém intervindo e

\footnotetext{
${ }^{16}$ Ver: http://cowparade.com.br/

${ }^{17}$ O Grupo Liberal, anteriormente denominado Sistema de Comunicação Rômulo Maiorana (entre 1986 e 1997) e Organizações Rômulo Maiorana (entre 1997 e 2018), é um conglomerado de empresas brasileiras sediado em Belém, PA, fundado em 1966 pelo jornalista e empresário Rômulo Maiorana, a partir da aquisição do jornal O Liberal das mãos de Magalhães Barata. Atualmente o Grupo Liberal é o maior grupo de comunicação do estado do Pará, o 9. ${ }^{\circ}$ maior grupo de comunicação do Brasil, e o $4 .^{\circ}$ maior grupo de comunicação afiliado a Rede Globo, através da Rede Liberal. (Ver: https://pt.wikipedia.org/wiki/Grupo_Liberal)
} 
ocupando vários pontos da capital, locais estratégicos como afirma a matéria ${ }^{18}$. Ficamos sabendo também que se trata de um evento de arte a céu aberto feito em homenagem aos 400 anos da cidade. O objetivo aqui é entender como se desenrola a articulação que leva às ruas da metrópole amazônica esta intervenção de "arte a céu aberto" em grande escala, usando os corpos de vacas como suporte artístico que, segundo a matéria, evidencia a mobilização de 44 artistas locais que teriam participado da ação.

Inicialmente chamamos a atenção para a expressão "vaquinhas", que aparece grifada no final da citação, pois esta denominação foi recorrentemente utilizada pelos organizadores do evento para se referirem as vacas de plástico. Esta forma específica de menciona-las nos diz muito sobre os sentidos que a organização do evento buscou dar às vacas sintéticas cujas presenças modificaram as paisagens da cidade. No site oficial do Cowparade Belém 400 anos justificam o porquê de usar esculturas no formato de vacas:

Há algo de mágico com a vaca. Ela representa coisas diferentes para pessoas diferentes ao redor do mundo: é sagrada, é histórica, mas o sentimento comum é de carinho. Ela simplesmente faz todos sorrirem. A escultura de vaca da CowParade forma uma tela tridimensional que agrada a todos os artistas e não existe nenhum outro animal ou objeto que fornece uma forma com a mesma flexibilidade e amplitude. As três poses de vaquinhas (em pé, pastando, repousando) oferecem para aos artistas ângulos e curvas para criarem obras de arte únicas. (colhido em 25-092018, site: http://www.cowparade.com.br/pa/)

As vacas seriam, assim, uma espécie de mimo totêmico numa sociedade de consumo, e seus corpos entendidos como substratos artísticos foram escolhidos, segundo os organizadores, porque "há algo de mágico com a vaca"; "ela é sagrada" e porque "o sentimento comum é de carinho". Aqui, a figura do bovino dos "bois bumbás" paraenses, e sua mitologia que narra as assimetrias sociais e ritualizam popularmente "a cultura do terror" (Taussig, 1993), transfigura-se no pop festivo e

\footnotetext{
${ }^{18}$ Em outro trecho conhecemos um dos personagens centrais desta trama, ou seja, a empresa que organiza a CowParade no Brasil: "Belém é uma cidade muito viva em suas cores, sabores e sons. Em todos os projetos percebemos o carinho e a atenção que os artistas dedicaram ao evento, que só traz benefícios para a cidade", explica Catherine Duvignau, sócia-diretora da TopTrends, empresa que organiza a CowParade no Brasil". (Jornal O Liberal, 19 de agosto de 2016) Note-se que a representante da empresa TopTrends fala sobre os benefícios trazidos pelo evento para a cidade, a matéria não evidencia quais são estes benefícios exatamente, sabemos que esta empresa é detentora do licenciamento da CowParade Holding e dos direitos de realizar este evento no Brasil, pois o CowParade é um produto que pode ser licenciado por empresas a fim de que se realize em qualquer lugar do mundo. Mais do que isso ela se tornou ao longo de sua trajetória um empreendimento multimilionário, e não por acaso, foi eleita como uma das 10 maiores ideias de Marketing entre 1.000, no ranking realizado pela Advertising Age (The Book of Ten - Ideas of the Decade) (2000).
} 
consumista que ressalta certa noção de "cultura"19, que ao mesmo tempo em que se apropria dos elementos ditos populares, o fetichiza em nome da arte e do bom gosto.

Ficamos pensando nestes argumentos considerando a presença e os significados dos corpos bovinos no contexto socioeconômico e geopolítico da região Amazônica, e mais especificamente no estado do Pará. Não há, ao nosso ver, como pensar na chegada desse rebanho de "vaquinhas" coloridas da CowParade que interveio na cidade de Belém a partir do dia 20 de agosto de 2016, alterando as paisagens locais, sem refletir sobre os rebanhos de bovinos que há décadas estão intervindo e alterando as paisagens de toda a região amazônica ${ }^{20}$, especialmente as paraenses e, não foi por acaso que o estado se tornou um dos maiores produtores de gado do Brasil. De fato, segundo dados da Pesquisa Pecuária Municipal 2016 do IBGE, o município de São Félix do Xingu, localizado no sul do Pará, possui o maior rebanho bovino do país com cerca de 2.213 milhões de cabeças de gado:

A região Norte, com 47,9 milhões de cabeças, teve o segundo maior efetivo do país, com alta de $1,7 \%$ em relação a 2015. (...) o deslocamento de bovinos para o Norte foi motivado pelos baixos preços das terras, pela disponibilidade hídrica e pelo clima favorável. (Site da agencia IBGE de notícias, matéria de 29-09-2017, colhido em 26-09-2018 ${ }^{21}$ )

Na Pesquisa Pecuária Municipal do IBGE do ano de 2018, o estado do Pará se aproxima mais ainda da marca de 50 milhões de cabeças de gado e o município de São Félix do Xingu (PA) continua a possuir o maior rebanho bovino do país, tendo aumentado o mesmo para cerca de 256 milhões de animais. Trata-se de um imenso rebanho de gado que tem avançado em direção ao Norte do país como uma marca da expansão da fronteira que é a Amazônia, originando grandes fazendas que passam a controlar cada vez mais as terras e recursos naturais disponíveis na região. Estamos nos

\footnotetext{
${ }^{19}$ Escamoteando o lugar do gado bovino como signo de poder transfigurado na carne consumida pelas famílias modernas, que historicamente evidencia assimetrias de raça - já que geralmente são brancos que comem mais carne; de gênero - uma vez que a devoração de carne sempre foi atributo masculino como expressão de supremacia sobre as mulheres - e, por fim, evoca o especismo carnista que inferioriza nãohumanos pela cultura, vendo bovinos como meros animais de corte para consumo de proteína, imagens típicas de sociedades patriarcais, heteronormativas e brancas. A crítica de Carol Adams (2012) é extremamente relevante. Para o caso do Karitiana vibra a imagem da "inveja do gado", desdobrada no poder dos fazendeiros pecuaristas. Para tanto ver Vander Velden (2011).

${ }^{20}$ A destruição do Bioma Amazônico pela imposição de pastagens para criação do gado bovino é uma figuração da ruína e da devastação da floresta entendida como signo de sujeira, impureza, já que nesta lógica é justo "limpar" o mato para introduzir pasto em seu lugar. A floresta, neste sentido, seria uma imagem da desordem, uma espécie de acúmulo de lixo ecossistêmico que impossibilita a nova ordem da produção em série do agronegócio. Por outro lado, os subprodutos da existência bovina em grandes manadas têm efeitos, como se sabe, nada desprezíveis sobre o aquecimento global já que apenas no Brasil responderiam por $17 \%$ dos gases de efeito estufa. Ver: http://www.observatoriodoclima.eco.br/rebanhobovino-responde-por-17-das-emissoes-de-gases-de-efeito-estufa-no-brasil/

${ }^{21}$ Ver site: https://agenciadenoticias.ibge.gov.br/agencia-noticias/2012-agencia-denoticias/noticias/16994-rebanho-de-bovinos-tem-maior-expansao-da-serie-historica
} 
referindo, portanto, a imensas áreas dedicadas a criação de gado de corte, cujos lucros são oriundos da exploração da carne bovina. O avanço desse rebanho tem como consequência direta a devastação da floresta amazônica, como fica evidente abaixo:

\begin{abstract}
A pecuária bovina é o uso do solo mais importante em todos Estados da Amazônia. É uma atividade, que, em geral, tem apresentado crescimento em todos os Estados. Esses fatos tornam a criação de gado a atividade econômica de maior impacto em toda a região. A pecuária bovina também está fortemente associada com o desmatamento da Amazônia, sendo sua causa imediata mais importante. As regressões realizadas neste trabalho mostram também que o crescimento da agricultura de larga escala, em vez de reduzir, amplia o impacto da pecuária sobre o desmatamento. As motivações para o investimento na criação de gado na Amazônia continuarão ocorrendo. A pecuária exige baixos níveis de capital, pouco preparo para o solo e tem poucas restrições associadas a relevo e a áreas livres de troncos em florestas recentemente desmatadas. Esses fatores tornam a pecuária a atividade mais intensamente associada aos processos de desmatamento na maior parte da região. Tal fato ainda está associado à baixa densidade dos rebanhos na região. A criação de gado bovino, normalmente, é extensiva, contando com números normalmente em torno de uma cabeça. Hectare. (Rivero; Almeida; Ávila; Oliveira, 2009: 63-64) (grifos nossos)
\end{abstract}

Nesse contexto de mercado e produção de gado em expansão, que se fundamentam na exploração da carne bovina à custa da destruição da floresta na Amazônia, como pensar na aludida "sacralidade" e no "carinho" que, segundo a organização do evento, as vacas despertam? Como é possível conceber uma exposição de arte a céu aberto em uma das principais cidades da Amazônia, sem relacionar as vacas sintéticas com as vacas de carne e osso? Como a sacralidade de vacas indianas se coadunam com as vacas-objeto criadas para matadouros? Como pensar em uma intervenção artística que usa corpos de bovinos sem refletir sobre a exploração destes corpos e sobre a relação entre a criação de bovinos e o bioma amazônico? Muito menos nos dilemas ritualísticos de um boi bumbá que revela miticamente as mazelas da exploração na Amazônia?

Ao que parece, no caso da exposição CowParade Belém 400 anos, essas questões foram colocadas de lado diante de certa "verdade" e "autenticidade", pois o que ficou evidente na concepção e na realização do evento em Belém foi o exercício por parte da organização e, de forma geral, de todos os envolvidos com a exposição, de dissociar as imagens das vacas sintéticas das existências das vacas de carne e osso, e parte desta dissociação aconteceu por meio da utilização pelos organizadores do evento da expressão "vaquinhas", para se referir especificamente as vacas de fibra de vidro. Esta expressão teve como objetivo diferenciar as vacas das outras e despertar empatia do público da cidade de Belém para as sintéticas, desta maneira e de algumas outras formas se buscou ocultar ou ignorar o fato de que os bovinos no Pará são sinônimo de 
lucro para uns à custa da devastação da floresta amazônica, da exploração dos corpos dos próprios animais e das pessoas que trabalham com eles.

Segundo a matéria do jornal O Liberal, de 19 de agosto de 2016, “jovens e consagrados artistas da cena paraense, e profissionais de áreas como o design, arquitetura e fotografia, também customizaram suas vaquinhas ${ }^{22}$ com elementos que marcam a cultura paraense". Ora, a fim de refletirmos sobre a dissociação entre os significados das vacas de plástico e daquelas de carne e osso, promovidas pelo CowParade apresentamos dois exemplos do dilema ético-estético que o referido evento coloca em questão.

$\mathrm{O}$ primeiro diz respeito às customizações "com elementos que marcam a cultura paraense", referidas na citação acima, e entre elas encontra-se a do arquiteto Rhodrigo Maia, chamada "Vaca Açaizeira" que, segundo a organização do CowParade Belém 400 anos, presta uma homenagem ao fruto - o açaí - alimento fundamental e que historicamente está associado à alimentação das populações paraenses.

Imagem 1:

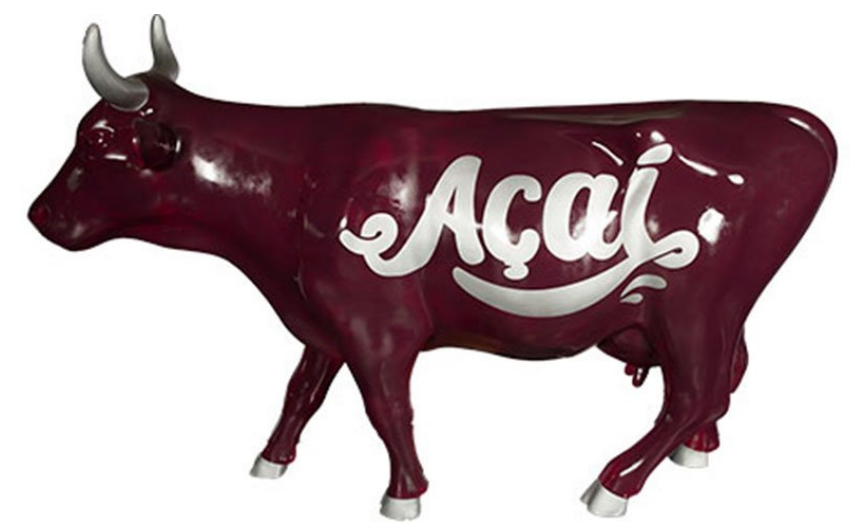

Sabe-se, por meio de um estudo coordenado por um pesquisador da universidade holandesa de Utrecht, que as palmeiras de açaí são as espécies mais numerosas que compõem a floresta amazônica, em outras palavras, não há como conceber a maior floresta tropical do mundo sem as palmeiras de açaí.

O consumo de açaí pode ter saído de moda no Sudeste do Brasil, mas na floresta amazônica a palmeira mantém presença dominante. É a árvore mais comum por lá, revela estudo de fôlego que sai hoje na revista "Science". O levantamento coordenado por Hans ter Steege, da Universidade de Utrecht (Holanda), reuniu dados sobre 1.170 parcelas espalhadas pelos 6 milhões de $\mathrm{km}^{2}$ da floresta amazônica (dois terços deles no Brasil). A principal conclusão é que, das estimadas 16 mil espécies arbóreas amazônicas, uma minoria de $227(1,4 \%)$ responde por metade dos 390 bilhões de árvores que o estudo calcula haver na maior floresta tropical do mundo. A espécie individualmente mais abundante é um tipo de açaí (Euterpe precatoria). Somado com o outro açaí que aparece em sexto na lista (E. oleracea),

\footnotetext{
${ }^{22}$ Grifo nosso.
} 
mais usado para alimentação, são 9 bilhões de plantas, mais de um açaí para cada habitante da Terra. (Jornal Folha de São Paulo, acesso em 26-09-2018)

A maior parte da extração de açaí no estado do Pará é feita de forma artesanal por populações ribeirinhas, e os pesquisadores que realizaram o estudo sugerem que as árvores mais abundantes da floresta, como é o caso das palmeiras de açaí, são também as mais úteis para os seres humanos e investigam se esse padrão pode ser resultado de um manejo da floresta feito ancestralmente por populações pré-colombianas, em outras palavras, sugerem que a floresta amazônica não seria tão "natural" como desejam muitos conservacionistas, mas fruto também das interações estabelecidas há séculos entre humanos e a floresta, interações que duram no tempo ${ }^{23}$.

As vacas ao longo de todo este período não estiveram presentes nessas paisagens, e ainda hoje não são marcantes nas paisagens ribeirinhas daqueles que continuam o trabalho ancestral de manejo e coleta de açaí, somente mais recentemente quando o aumento exponencial da venda do açaí, cujo consumo se tornou moda no centro-sul do país, permitiu que seus produtores na Amazônia pudessem ter recursos para comprar a carne bovina, que passou a estar na mesa ${ }^{24}$. Neste contexto, como podemos compreender esta homenagem "Vaca Açaizeira", considerando que existe uma vinculação direta e paradoxal entre a expansão da criação de gado e o aumento da devastação da floresta amazônica, na qual as palmeiras de açaí são predominantes?

O segundo dilema associativo, ou melhor, dissociativo, é a curiosa vinculação entre as vacas sintéticas e as vacas de carne e ossos, neste caso, envolvendo a customização feita por Patrick Sandre na criação da "Vakaiapó", que segundo a organização da CowParade presta uma homenagem ao povo indígena Kayapó.

\footnotetext{
${ }^{23}$ Ver Balée (2013). No site do El País - Brasil, seção Ciência, em 03/03/ 2017, consta o seguinte: "Muito antes de os europeus desembarcarem nas costas da América, em 1492, os povos indígenas tinham mudado a paisagem da Amazônia ao longo de milhares de anos. E os efeitos de suas atividades definem as características atuais da floresta. Uma pesquisa realizada por Carolina Levis, especialista em ecologia do Instituto Nacional da Amazônia (Brasil), e publicada nesta quinta-feira na revista Science, demonstra que as espécies vegetais domesticadas pelas civilizações pré-colombianas são as mais dominantes." (https://brasil.elpais.com/brasil/2017/03/02/ciencia/1488466173_526998.html)

${ }^{24}$ Sobre a alimentação de populações ribeirinhas no contexto belenense ver Beltrão e Rodrigues (2005).
} 
Imagem 2:

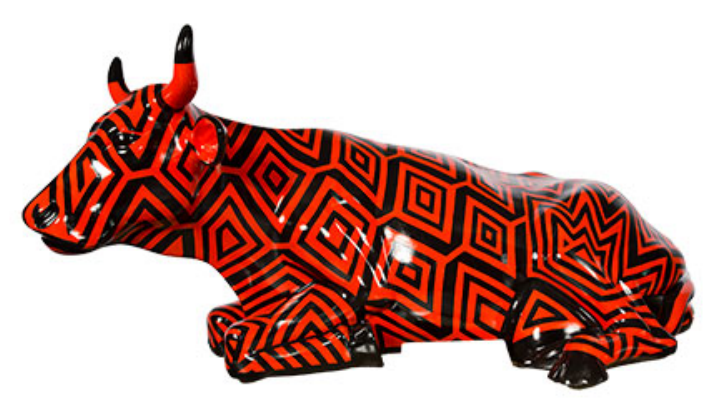

Como compreender tal homenagem se na Amazônia, e em outras regiões do país, os bovinos sempre estiveram associados às fazendas de criação de gado, e sabemos dos inúmeros conflitos causados pelo avanço de fazendas de criação bovina sobre terras indígenas - e aqui evocamos novamente o artigo de Vander Velden (2011) - que resultaram na destruição de grandes áreas florestadas, ambientes e ambiências fundamentais para os diversos modos de vida de povos indígenas, incluindo os Kayapó.

Parece-nos que conceitualmente e de forma prática algumas obras da CowParade realmente se distanciam das relações e dos significados que envolvem a existência dos bovinos de carne e osso no contexto amazônico, a própria forma de conceber as esculturas das vacas de fibra de vidro como suporte artístico nos dá pistas para compreendermos as referidas dissociações: os organizadores do CowParade Belém 400 anos justificam o uso do corpo bovino como suporte para arte, porque o mesmo se apresenta como uma "tela tridimensional que agrada todos os artistas e que nenhum outro animal tem a mesma flexibilidade e amplitude", sem explicar a que amplitude e flexibilidade se referem, o que fica evidente é o exercício de usar estes corpos bovinos pensados apenas como telas, como simples suportes para que se faça qualquer pintura, como se fosse possível destituir, separar, forma e conteúdo, transformando a forma animal em simples tela tridimensional, dissociando o suporte artístico dos sentidos e significados que o animal (que lhes dá dimensões formais e serve de referência) possui nos diversos contextos em que está presente. Neste sentido, parecem querer que a tela tridimensional se sobreponha a existência do animal e seus significados, transformando o bicho, o animal, o ser vivo não humano em simples objeto para a representação, a partir de uma noção singularizante de "cultura" paraense, quando ela é plural, inclusive, na metrópole.

De certa forma, parece que retirada do contexto original em que foi criada, na Suíça, onde as vaquinhas das quais se extrai o leite para fazer chocolates são comuns, a 
exposição CowParade foi pasteurizada, o corpo-vaca pulsante de significados transformou-se simplesmente em uma tela tridimensional "que agrada todos os artistas", uma tela que se distancia do significado local dos bichos de carne, ossos, sangue e nervos espalhados pelo mundo e dos contextos sociais, políticos e ambientais que os envolvem e com os quais interagem transformando-se numa alegoria da "cultura".

Ambas, vacas sintéticas transfiguradas em simples telas tridimensionais e vacas de carne e ossos no final das contas possuem trajetórias que de certa forma se assemelham bastante, as duas são tratadas como objetos, propriedades privadas, usadas como mercadorias, e tal como as de carne e ossos, ao final da exposição as vacas sintéticas também são vendidas. Na forma como a CowParade é realizada, ou ao menos como foi realizada na cidade de Belém, as vacas sintéticas não nos provocam a pensar nas vacas vivas, nem nas relações éticas que se estabelecem entre humanos e estes não humanos, e nem ao menos nos provocam a ter empatia ou interesse pelas existências das vacas vivas. De fato, a exposição parece reforçar dissociação semelhante a de uma criança que se alimenta de carne bovina, mas não tem ideia do que é, e de onde provém o alimento ingerido no seu afã carnista ou por laticínios. Aqui a vaca-bibelô se distancia da vaca-bife ou leiteira, e a ética e a estética na arte ficam à deriva na urbe, numa tensão de representações que se falam da realidade acusam meias-verdades.

\section{As intervenções nas intervenções urbanas: o avesso da "vaquinha"}

No que se refere as ações de intervenção dos artistas locais, cujas práticas no mundo da arte se dão na cidade anfitriã em relação, ou sobre os artefatos estéticos (as vacas) da exposição da CowParade, que se insere numa lógica da arte-consumo nas paisagens urbanas, percebemos que foram inúmeras as intervenções de artistas nas várias cidades sobre as superfícies das vacas sintéticas, em geral a coordenação da CowParade trata e classifica tais intervenções como "vandalismo", ou em certos casos, imbuída de moralismos, censura o artista, buscando desqualifica-las como uma espécie de avesso da arte. Sabe-se que em cada evento a coordenação do CowParade possui uma equipe pronta para "restaurar as vaquinhas que foram vandalizadas", o que por si só indica a frequência com que as pessoas que praticam as cidades interagem e intervêm nas vacas sintéticas da exposição.

A forma de tratar as interações, taxando-as de "vandalismo", faz com que as intervenções das pessoas nas vacas não venham com frequência a público na cidade onde ocorreu o ato criativo, porém, algumas delas foram impossíveis de ocultar pelos organizadores. Citamos três exemplos de intervenções que vieram a público e foram 
muito bem tratadas no excelente artigo intitulado: "Banksy vs. CowParade: Os limites da arte urbana". publicado no blog do Coletivo Laborativo ${ }^{25}$.

No ano 2000, na $3^{\circ}$ edição do CowParade realizado na cidade de Nova Iorque (EUA), a vaca criada pelo diretor, roteirista e produtor de cinema David Lynch foi simplesmente censurada. Ou seja, desde o início da trajetória do evento ficou evidente que, caso necessário, a censura seria uma das formas de atuação dos organizadores em relação às obras elaboradas sobre a superfície dócil das vaquinhas. Neste sentido, o trecho abaixo é elucidativo:

A Cow Parade também recebeu críticas por seus padrões de seleção, pois geralmente
política, sexo e religião são temas vetados na exposição. Em 2000, na edição nova-
iorquina, o projeto do cineasta David Lynch foi censurado pelos organizadores. A
vaca de Lynch é decapitada, sua cabeça sangrenta descartada dentro do corpo da
própria vaca, que é rasgada. Garfos e facas fincadas em seus flancos, rasgando a
carne de vaca. Através de seus lados a frase "coma meu medo" é escrita. (texto e
imagem
colhidos $\begin{array}{lcc}\text { imagem colhidos } & \text { em } & 02 / 05 / 2020 \\ \text { http://laborativo.blogspot.com/2012/09/banksy-vs-cow-parade-os-limites-da- }\end{array}$ arte.html)

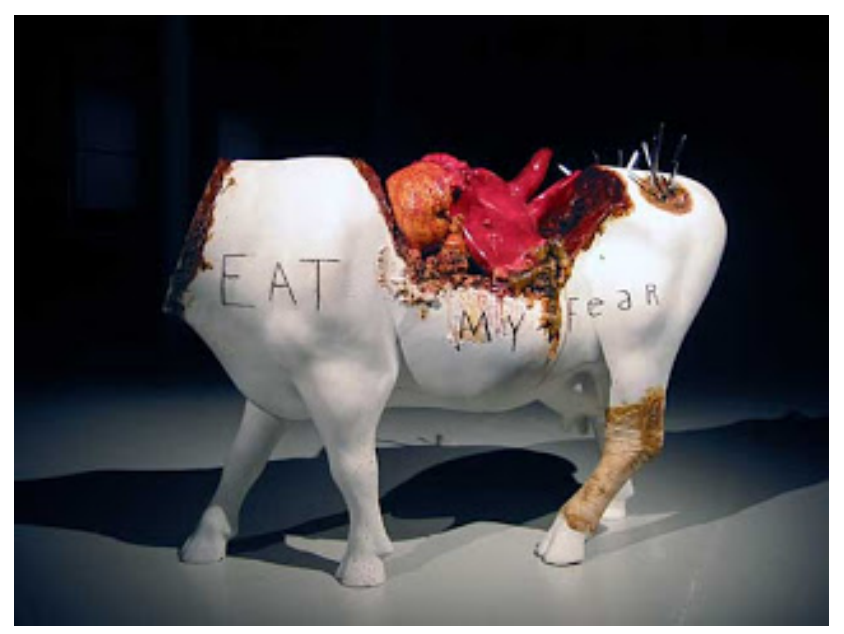

Vaca censurada de David Lynch, 2000

No ano de 2004, na $7^{\circ}$ edição do CowParade realizado na cidade de Estocolmo (Suécia), a ação direta foi feita por um grupo de artistas grafiteiros que fizeram questionamentos à coordenação do evento, exigindo que a mesma reconhecesse que a CowParade não era arte. O impasse com certo tom de deboche ocorreu por intermédio de um episódio performático, quando:

$[\mathrm{u}] \mathrm{m}$ grupo intitulado Grafiteiros Militantes de Estocolmo sequestrou uma das vacas expostas na capital sueca, como protesto contra vacas publicitárias carregando anúncios, e ameaçou "sacrificá-la" a não ser que as esculturas fossem declaradas

\footnotetext{
${ }^{25}$ Ver: http://laborativo.blogspot.com/2012/09/banksy-vs-cow-parade-os-limites-da-arte.html
} 
pela organização do evento como "não-arte". Para atrair a atenção da mídia, eles divulgaram um vídeo, que me lembra muito aqueles terroristas da Al-Qaeda, em que dois encapuzados posavam com serras na mão ao lado da vítima indefesa. (colido em 02/05/2020 em: http://laborativo.blogspot.com/2012/09/banksy-vs-cow-paradeos-limites-da-arte.html)

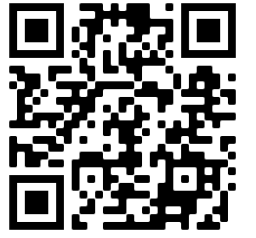

O vídeo chamado "cowparade stockolm" foi publicado no You Tube. Use o leitor de QRCode do seu celular e assista aqui o vídeo dos grafiteiros. (colhido em 03/05/2020 em https:/www.youtube.com/watch?v=AdY1Sc-w1vE)

No ano de 2010, na $12^{\circ}$ edição do CowParade e a $2^{\circ}$ edição na cidade de São Paulo (Brasil) ocorreu o terceiro episódio que destacamos. Se na primeira intervenção que citamos foi questionada a censura do CowParade, e na segunda intervenção os grafiteiros questionaram se o evento é realmente arte, nesta terceira o artista Eduardo Srur interage com o público questionando o que a coordenação do CowParade chama de corpo-tela, que são os corpos das vacas. Nesta intervenção Eduardo restitui e evoca os significados destes animais na vida cotidiana, e faz ponderações sobre usar corpos de vacas como suportes para a arte, criando obras completamente descontextualizadas do modelo "vaquinhas" acionando um caráter irônico à obra.

Em 2010, o artista Eduardo Srur rouba a cena da Cow parade, realizando uma intervenção em que o "Touro Bandido", conhecido por seu instinto indomável e pela participação na novela América, foi colocado em posição de acasalamento com duas vacas da exposição, em São Paulo. A intervenção viria a questionar essa arte internacional, pois Srur não vê relação entre a vaca e a cidade de São Paulo. Com as réplicas do touro, ele tenta resgatar o imaginário nacional com o animal que se tornou lenda nacional. E continua alfinetando: "A CowParade é obra de reflexão artística ou um trabalho de marketing muito exposto no resultado final?" "A vaca ficou estéril de reflexão simbólica e vem o touro e cria uma inseminação artística. Não vejo nenhuma relação entre a vaca, símbolo de outro país, e a história de nossa cidade. [...] O touro, sim, traz questionamentos: basta colocar um objeto na rua para ser arte pública? Não será preciso gerar algo mais para o espectador participar daquilo que vê? Um projeto de arte pública ou arte no espaço público deve trazer questões originais, relacionar-se com o espaço ocupado." diz Srur em entrevista. E continua "se o Touro Bandido não tivesse um BO (Boletim de Ocorrência), não seria bandido [risos] e não iria acontecer essa discussão sobre os limites e a fronteira da arte no espaço público". Aqui, o touro foi retirado pela organização do evento, com boletim de ocorrência registrando ato obsceno, difamação e danos materiais. (texto e imagens colhidos em 02/05/2020 em: http://laborativo.blogspot.com/2012/09/banksy-vs-cow-parade-os-limites-daarte.html) 


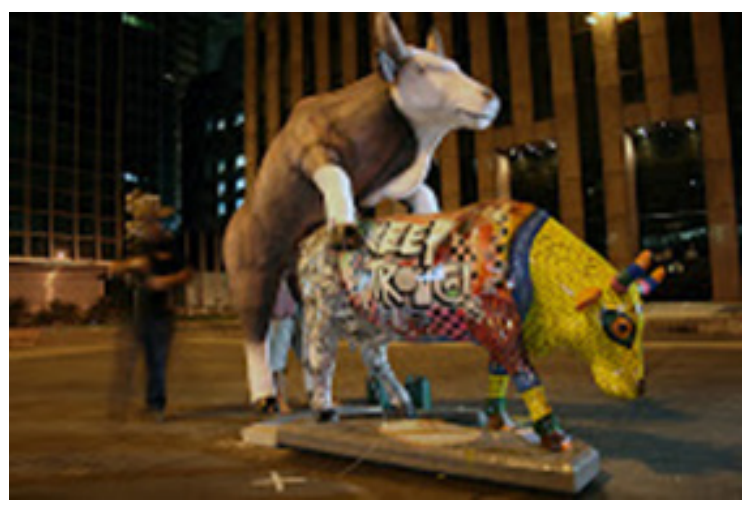

Eduardo Srur. Touro Bandido, 2010.

Av. Paulista, São Paulo (SP)

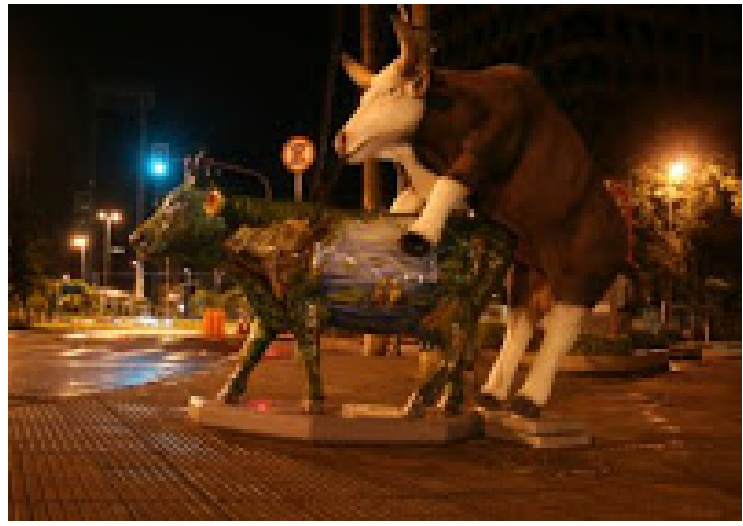

Eduardo Srur. Touro Bandido, 2010.

Av. Brigadeiro Faria Lima, São Paulo (SP)

As três intervenções demonstram a existência de formas de questionamentos que se aproximam de táticas (Certeau, 1994), que na medida que apresentam certas potências de subversão do contexto em que se inserem, reintroduzem a crítica como uma das dimensões da arte urbana, e oferecem certo caráter contra-hegemônico. Não se trata aqui de reificar uma arte crítica e revolucionária, mas sim de se pensar além da arte pela arte focada numa experiência estética de consumo e marketing: não é o caso de pensar a obra em si, mas para o caso que nos interessa, no que se desdobra dela a partir da vida vivida na Amazônia que considere as suas contradições.

Mas, ainda assim a CowParade não deixa de ser uma intervenção em grande escala na vida das cidades, interferindo de forma intensa nas paisagens urbanas e criando imagens que se relacionam com aspectos importantes das culturas locais e ao 
chamado marketing cultural ${ }^{26}$. Estas intervenções, entretanto, trazem algumas questões centrais relacionadas, por exemplo, as reações ou protagonismos dos habitantes das cidades sobre o rebanho colorido de vaquinhas, em outras palavras, questões ligadas as reações em relação aos organizadores da CowParade, que intervêm na cidade com uma exposição de arte pública, quando a urbe por meio de seus artistas agem na própria exposição, alterando as obras originais, fazendo uma espécie de intervenção na intervenção artística.

O Laborativo, grupo fundado em 2011, é um exemplo de coletivo que discute arte e tece questões importantes sobre o CowParade. Por meio do seu blog ${ }^{27}$ apresentam várias informações relacionadas às críticas feitas ao evento em diversos lugares do mundo, e sintetizam alguns dos questionamentos centrais em relação ao evento que achamos pertinentes refazer, neste caso, voltado ao nosso propósito de reflexão para o contexto belenense: são obras de arte, ou apenas uma nova maneira de vender? Trata-se de uma mercadoria onde o patrocinador expõe sua marca? Podemos chamar de arte pública, ou de arte democrática?

Mas o que nos parece bastante contraditório é que a mesma organização do evento que promove uma tal intervenção artística fique ressentida quando outras intervenções artísticas acontecem dialogando com as obras "originais", aqui nos referimos as várias intervenções que artistas de diversas cidades pelo mundo fizeram nas vacas da exposição, como nos referimos antes, mas no caso específico da CowParade Belém 400 anos indicamos a pixação que uma artista belenense elaborou no corpo de uma das vacas da exposição.

A agência da artista de Belém não se constitui como um ato isolado, mas em algo que se repetiu de maneira diferente em várias outras cidades, quando artistas locais realizaram intervenções artísticas na intervenção operada pela CowParade. Em todas estas ocasiões, a cidade ao nosso ver dialogou mais concretamente com a proposta artística, quando então os citadinos abandonaram uma posição de expectadores passivos

\footnotetext{
${ }^{26}$ Este aspecto complexo de um evento de intervenção de arte pública a céu aberto, como se define o CowParade, mas que ao mesmo tempo recebe prêmio internacional de marketing de importante publicação especializada, revela uma questão relevante sobre esta exposição: a sua dúbia existência entre arte e marketing. Este aspecto ambíguo ensejou estudos importantes sobre o tema, entre os quais destacamos a pesquisa de Tanise Pozzobon (2011) sobre a CowParade realizada na cidade de Porto Alegre, quando afirma o seguinte: "O marketing cultural apropria-se da arte contemporânea como uma ferramenta para a construção da imagem de uma empresa, marca ou produto... [o que demonstra] as peculiaridades do evento, utilizando-o como um exemplo das implicações do patrocínio privado na arte contemporânea" (Pozzobon, 2011: 4).

${ }^{27}$ Ver artigo intitulado "Banksy vs. Cow Parade: Os limites da arte urbana" no endereço eletrônico do coletivo laborativo: (http://laborativo.blogspot.com/2012/09/banksy-vs-cow-parade-os-limites-daarte.html) colhido em 25/07/2019.
} 
que recebem a intervenção e passaram a participar da criação ativamente, intervindo artisticamente na intervenção de "arte pública" como se define a CowParade, na medida em que o debate sobre arte pública é tensionado.

Quando afirmamos que as intervenções nas obras originais das vacas do evento são uma ação dos cidadãos sobre a exposição, e não apenas ações individuais, é porque mesmo que a intervenção tenha sido feita por um, uma ou um grupo de artistas, estas ações dialogam com imaginários locais produzindo novas obras e novas paisagens na cidade, de certa forma, a cidade (e seus praticantes) por meio da intervenção dos seus artistas situados fora do jogo midiático, subvertem a exposição ao se apropriarem dos corpos das vacas re-significando-as nos contextos locais, indo além do que os organizadores do encontro permitem, ou não, que se realize. Desta forma, a cidade reaproxima as vacas sintéticas dos sentidos das vacas e bovinos existentes nos contextos locais, criando imagens híbridas onde as fibras de vidro daquelas esculturas aproximam nossas sensibilidades dos viventes não humanos de carne, ossos e nervos.

Assim, estas ações de interferência nas obras originais trazem algumas questões fundamentais: O que é arte pública? Quais os limites de uma intervenção de arte pública? Quem define o que é ou não arte? E nos faz pensar sobre os limites das interações das pessoas com as obras de arte expostas em intervenções de arte pública, ao que parece, uma artista de Belém não se contentou em apenas contemplar "as vaquinhas".

\section{Eu pixo, tu pixas, ela pixa: a "vaca profana" da arte de rua entre o belo e o} dejeto

Imagem 3:

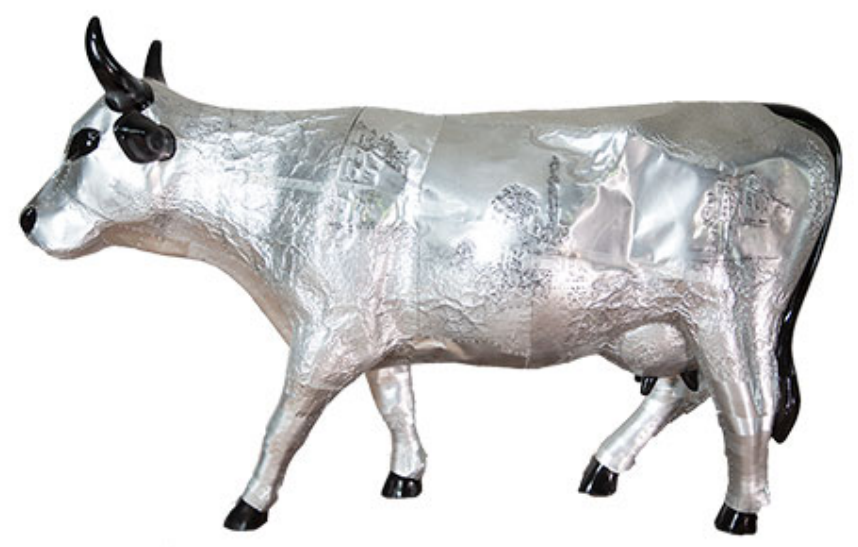

Foi esta vaca reluzente que a jovem artista de Belém viu ao dobrar a esquina da Avenida Nazaré com a travessa Quintino Bocaiúva, no centro da cidade. Diante da cena 
e carregando sua lata de spray laranja, ela não titubeou. Ao se aproximar do corpo bovino sacou o spray e pixou a palavra NAUFRÁGIO, realizando uma intervenção sobre a intervenção urbana. Ali, o pixo assume o seu lugar político de street art e resitua a arte de consumo a partir de uma manifestação ético-estética das ruas diretamente ligada ao mundo urbano paraense.

Imagem 4:

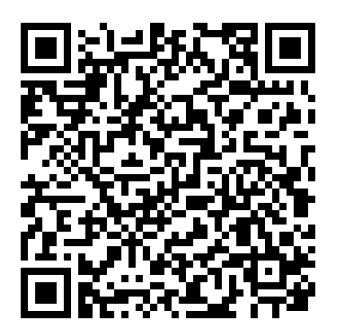

Momento exato da Pichação ${ }^{28}$.

Diferentemente das outras 49 vacas da Cowparade espalhadas pela capital paraense, a obra do artista Jocatos, intitulada "Noites brancas", que consta como o número 21 da Galeria das Vacas no site oficial do evento, era a única vaca (praticamente) monocromática de toda exposição. Não que conscientemente Jocatos tivesse de propósito transformado sua obra em uma nova tela, mas de qualquer forma foi como uma tela reluzente que a artista percebeu "a vaquinha" na Avenida Nazaré. Sensivelmente a artista interveio conectando definitivamente dois eventos que aparentemente não tinham nenhuma ligação entre si no contexto paraense, refazendo a conexão entre as vacas sintéticas e os bovinos de carne e ossos, que a Cowparade insiste em dissociar.

\footnotetext{
${ }^{28}$ Para todas as imagens de QR Code (hyperlinks para vídeos) que seguem no texto, baixe um aplicativo leitor de QR CODE para o seu celular, aponte para a imagem e assista aos vídeos correspondentes a cada momento.
} 
Imagem 5:

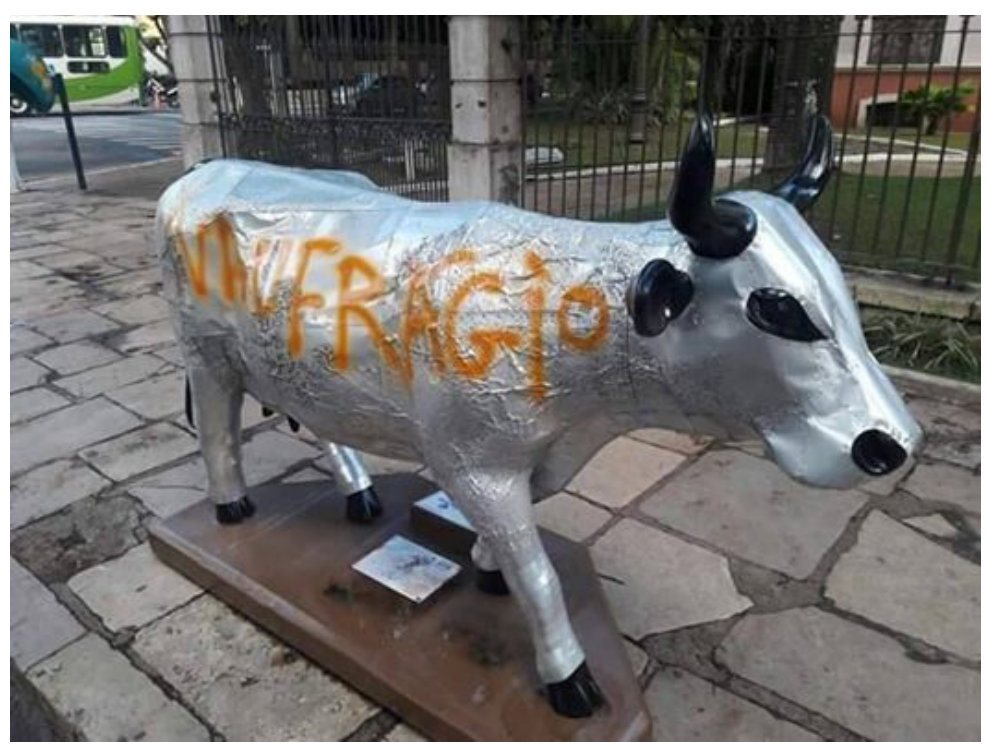

O diálogo que mantivemos com Métis indica primeiramente a sua relação com Íris, idealizadora de um projeto $^{29}$ de ações artísticas no contexto de Barcarena, que considerava as problemáticas ligadas a convivência das pessoas com o complexo industrial presente na cidade, relacionado a exploração do alumínio ${ }^{30}$. Todavia as suas ações se estenderam a Belém.

Ambas teriam decidido realizar a intervenção sobre o corpo da vaca a partir da consciência dos dramas vividos por humanos e não-humanos no contexto de Barcarena, cidade próxima a capital, pois segundo Métis "aquela ação" fazia parte de um "conjunto de outras" que denunciavam, sensivelmente, os horrores da degradação socioambiental na Amazônia urbana. Além, de tais problemáticas somava-se o recente naufrágio ocorrido nas proximidades da Vila do Conde, que vitimara milhares de indivíduos de

\footnotetext{
${ }^{29}$ Projeto ao qual teriam se juntado mais duas pessoas.

30 “O governo militar elaborou o Programa de Desenvolvimento Regional Infraestrutura do Complexo Albrás/Alunorte em 1978 e seguido a este constitui mediante o Decreto No 84.021 de 24 de setembro de 1979 a Companhia de Desenvolvimento de Barcarena - CODEBAR, baseado nos termos da Lei no 6.665, de 3 de julho de 1979, com caráter de empresa pública, vinculada ao Ministério do Interior, até que a União deixe de participar do seu capital. O Decreto de criação foi assinado pelo presidente João Figueiredo. No Estatuto determina-se no Artigo $3^{\circ}$ - A Companhia tem por objetivo a execução e a administração de obras e serviços de urbanização, em áreas destinadas ao assentamento humano de apoio à instalação e ao funcionamento do complexo Artigo 3o - A Companhia industrial metalúrgico no Município de Barcarena. (...) A CODEBAR coerente com as finalidades atribuídas produziu uma leitura do espaço físico do município de caráter excludente e autoritário. A unidade de planejamento foi a "quadra-lote", A expropriação substituiu a categoria sitio dos povos e comunidades tradicionais pela categoria quadra-lote, o que denota profunda violência e transformação geopolítica dos territórios, que além da pressão das empresas, do Estado também sofreu com a pressão de milhares de pessoas que migraram para a região para trabalhar no empreendimento mineral Albraz, Alunorte." (Acevedo Marin, 2014: 14 e 19)
}

Iluminuras, Porto Alegre, v. 21, n. 54, p. 527-568, setembro, 2020. 
gado bovino ${ }^{31}$. Daí a "surpresa" para a artista com o CowParade que ocorria na cidade e o fato de "ninguém falar nisto", ou ainda, "sobre a questão da morte dos bois, ninguém!”, simplesmente tocara no tema. Daí, no seu ponto de vista era preciso pensar o "papel omisso que a arte muitas vezes tem, né. Não só a arte, mas boa parte da sociedade, enfim". O que surpreendeu as jovens artistas era justamente a arte estar destituída de "problematizações políticas" naquele contexto repleto de contradições.

A agência ético-estética de pixar a "vaquinha" não teria sido planejada com muita antecedência, ainda segundo a artista as "tintas spray" estavam destinadas para "fazer uns stencils" no âmbito de suas intervenções urbanas. A perplexidade de ambas as artistas diante do desinteresse dos artistas sobre tais problemas ficou evidenciado na visão das vacas distribuídas pela cidade: “aí eu falei que tava a fim de pixar uma vaca dessas, porque eu achava um absurdo que nenhum artista tivesse falado... levei o spray dentro da bolsa... bora pixá a vaca!"

A intencionalidade do pixo não tinha uma vaca específica, um alvo, como fica claro na fala de Métis: "a gente não escolheu a vaca, assim, e por sorte era uma que tinha alumínio, prateado". Por outro lado, a cor laranja da tinta utilizada na ação possuía um sentido evidente "porque é uma referência a cor do rejeito que é gerado pelo beneficiamento da bauxita, do alumínio". Tratava-se de um acaso criativo, um "momento feliz", no sentido bachelardiano (1988) de uma fenomenologia da imaginação criadora. A vaca prateada que evocava a imagem do extrativismo violento do alumínio reverberava na cor laranja do pixo NAUFRÁGIO, que desdobravam-se tanto nas imagens terrificantes dos rejeitos industriais quanto da massa amorfa de bois putrefatos.

Derivas e convergências de imagens emergem na sua agência. Ao pixar a palavra NAUFRÁGIO numa das vacas da CowParade a artista ampliou conceitualmente este objeto estético, dando margem a novas possibilidades de leituras ético-estéticas e políticas sobre o lugar dos bovinos no âmbito regional e global em um contexto de degradação socioambiental. Ela instaurou um processo de $\operatorname{artificação~}^{32}$. A artista interveio no corpo da vaca sintética para chamar a atenção para a agonia e morte de um rebanho cem vezes maior do que as cinquenta vacas sintéticas da CowParade que

\footnotetext{
${ }^{31}$ Retomaremos na próxima sessão o episódio catastrófico do naufrágio, de maneira a demonstrar com mais detalhes algumas de suas feições. No entanto, em relação aos dilemas decorrentes da extração e beneficiamento de minérios na cidade de Barcarena não adentraremos na questão neste artigo, ficando o tema para momento oportuno.

${ }^{32}$ Para Shapiro (2007:135-36) “[a] artificação é a transformação da não-arte em arte”. Neste caso, de uma pretensa arte noutra forma de arte. Ela "participa de um movimento geral de objetivação da cultura, atingindo todas as sociedades.".
} 
tomaram a cidade de Belém e das populações humanas que sofrem com a destruição dos ecossistemas, que são seus lugares de pertença.

\section{O Naufrágio, ou a Nau Frágil: pensando o cenário de uma tragédia socioambiental na Amazônia}

No dia 5 de outubro de $2015^{33}$ aproximadamente cinco mil bois vivos tinham acabado de ser embarcados às pressas no Haidar, um navio de bandeira libanesa, quando, de repente, o imenso e antigo artefato de contêineres mal adaptados para figurar como navio boiadeiro, paulatinamente, começou a virar e afundar no píer do porto de Vila do Conde, município de Barcarena, um dos principais portos do estado do Pará. Segundo Lucio Flavio Pinto:

O Pará é o maior exportador de boi vivo do Brasil e o quarto maior do mundo. Tem o quinto maior rebanho bovino do país e é também o quinto em abate de animais. (...) A cena chocante de enormes navios carregados com até 20 mil cabeças de gado para viagem de alguns dias até a Venezuela e quase um mês até o Líbano se tornou comum e virou rotina. (Fonte: Página eletrônica de Lucio Flavio Pinto, publicada em 26-10-2015. Fonte:https://ucioflaviopinto.wordpress.com/2015/10/26/o-naufragioe-o-para/ )

Imagens $6 ; 7 ; 8$ :

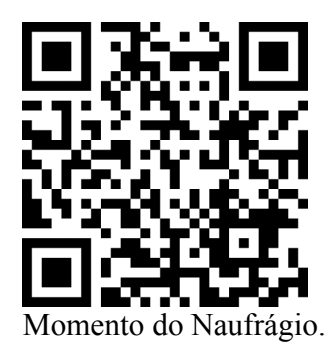

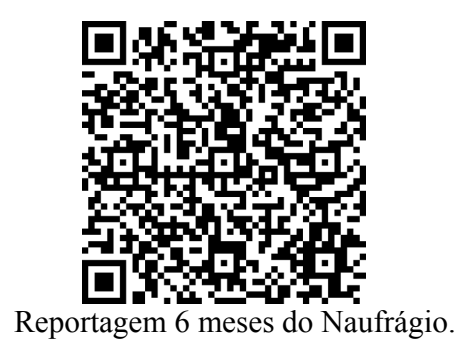

Reportagem 6 meses do Naufrágio.

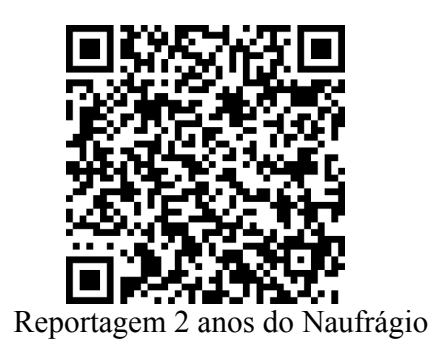

\footnotetext{
${ }^{33}$ Menos de 11 meses antes do início da exposição Cowparade Belém 400 anos.
} 
Imagens 9; 10:

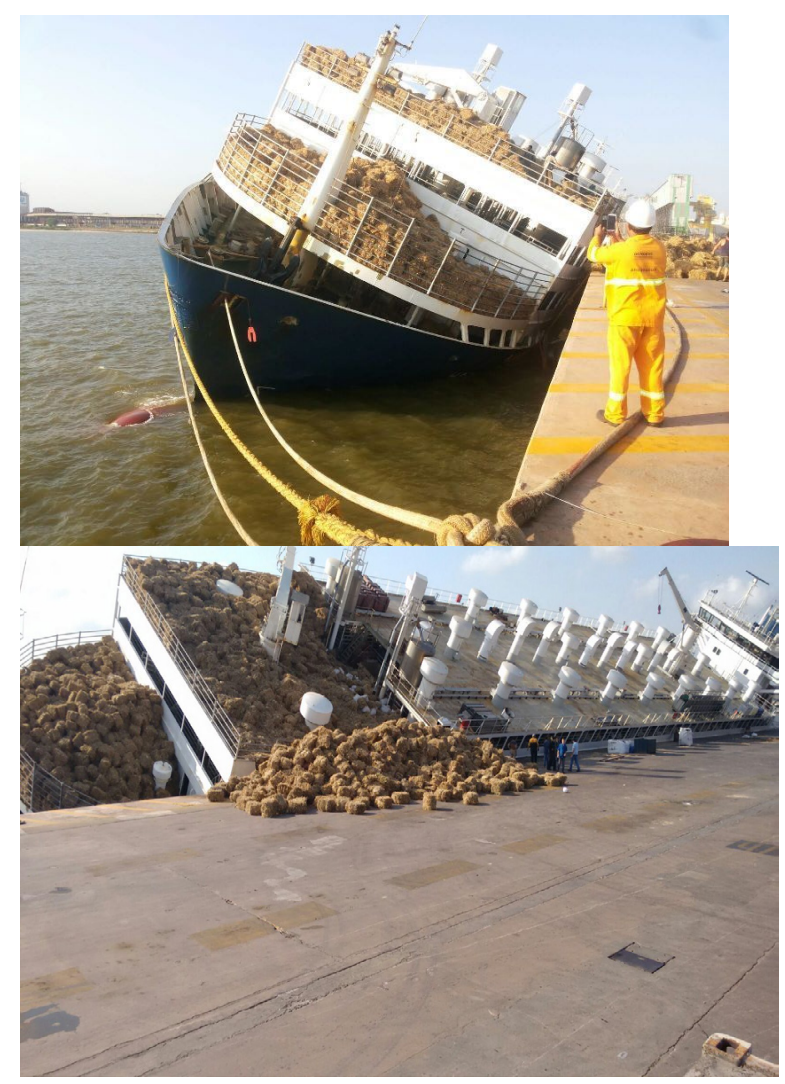

Imagens 11; 12 :
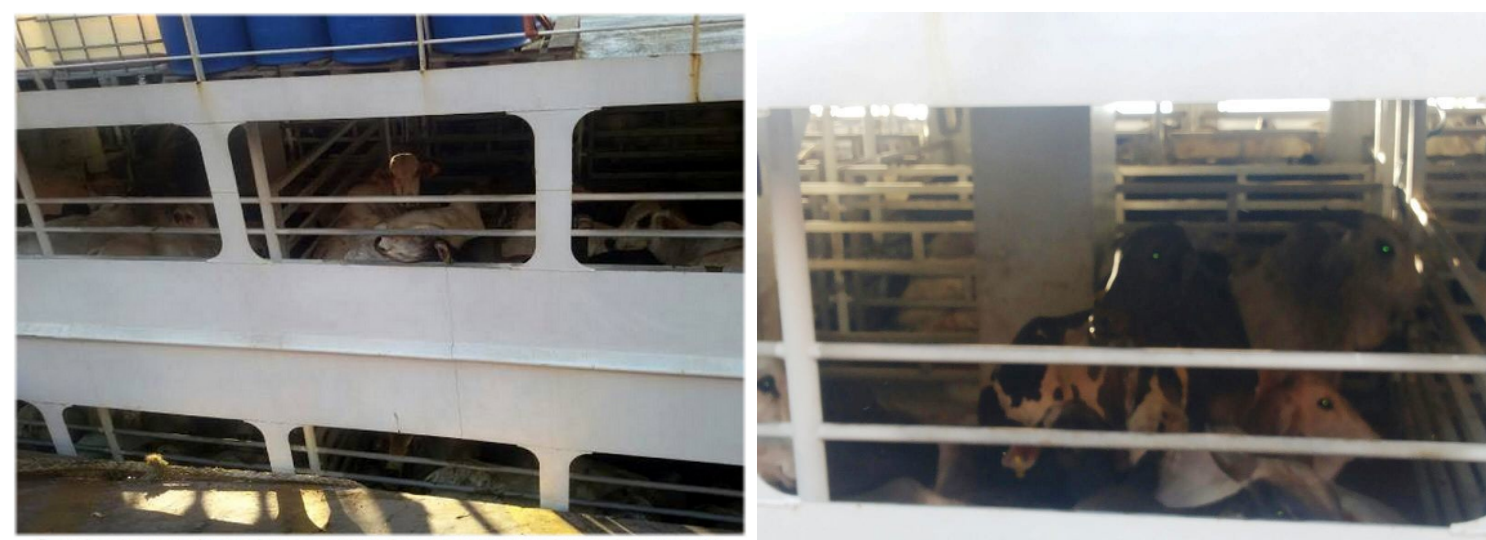

O navio adernou sobre o pier, o que obstruiu as portas por onde o gado escaparia

Na cena trágica que se seguiu ao embarque naquele dia foi possível perceber que as pessoas, impotentes, observavam o navio gigante afundando, enquanto os bois presos na carcaça da velha nave agonizavam lentamente, morrendo afogados aos milhares. Estas cenas foram reveladas pelas fotos divulgadas na imprensa local, sendo que em 
algumas delas é possível ver o rosto dos animais enquanto a água vai engolindo-os junto com a embarcação ${ }^{34}$.

Em uma cena surreal alguns bois se esgueiraram pelas frestas das grades da embarcação e subiram na carcaça do navio emborcado que naufragava lentamente, mas a saga dos animais não terminou aí, pois quando a embarcação foi ao fundo tiveram, ainda, que nadar até a praia, e outros tantos morreram nesta tentativa desesperada de sobreviver. As imagens na imprensa local seguiam compondo os quadros de horror.

Imagens 13; 14 :
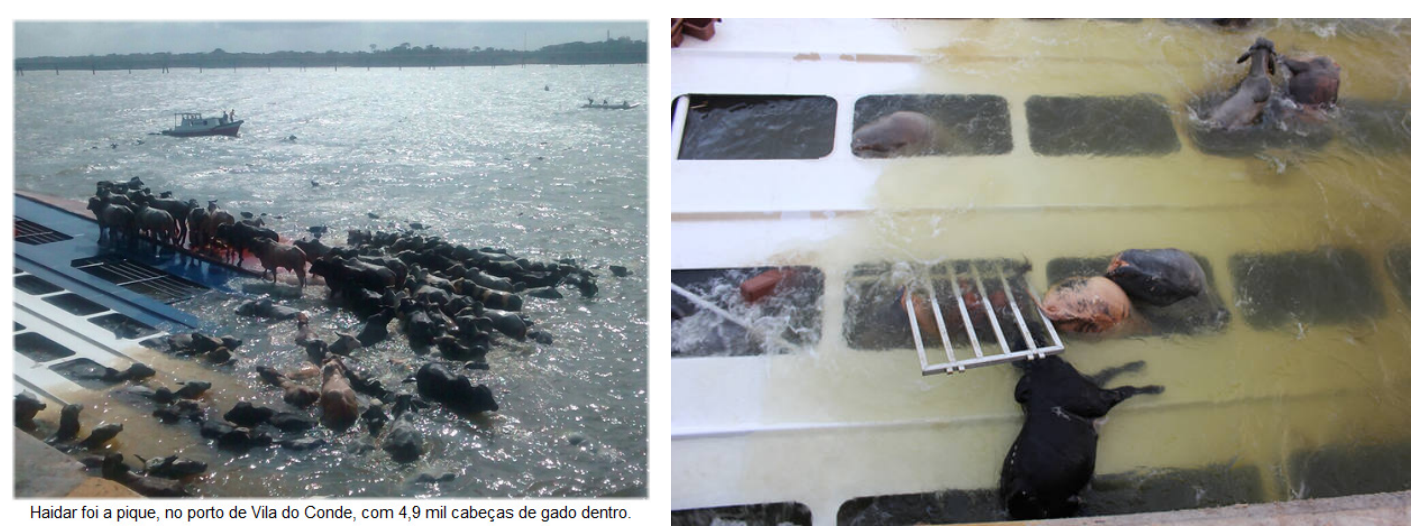

${ }^{34}$ Conforme o relatório do Ministério Público, referente ao Processo: 0028538-38.2015.4.01.3900: “A
embarcação "Haidar" naufragou lateralmente para estibordo, sendo que somente a parte traseira
submergiu completamente $\left(01^{\circ} 322^{\prime} 10,6\right.$ "S, $048^{\circ} 45^{\prime} 05.2^{\prime}$ W). O local do sinistro apresentou grande
quantidade de óleo bruto limitado inicialmente pelas boias de contenção. O acidente ocorreu no Pier 300
do porto de Vila do Conde, em Barcarena, tendo sido comunicado à Capitania dos Portos apenas por volta
das 8:00. Embora os números ainda sejam imprecisos, sabe-se que não mais de 30 animais foram
resgatados com vida, enquanto outros animais (cuja estimativa oscila em torno de 200 ) chegaram a deixar
a embarcação antes do naufrágio, alguns dos quais foram abatidos pela população, enquanto a expressiva
maioria, morta por afogamento, remanesceu inicialmente flutuando, em contenção realizada no local, a
qual veio a se romper, ocasionando a chegada dos corpos a diversas áreas da região, de modo que
aproximadamente 3.900 (três mil e novecentas) carcaças ficaram presas no interior da embarcação
naufragada. O acidente ocasionou ainda o derramamento de óleo marítimo MF 380 e de uma série de
outros resíduos, em especial feno destinado à alimentação dos animais durante o transporte. Estima-se
que o resíduo oleoso seja de aproximadamente 700 mil litros e as carcaças dos animais cheguem a 2.450
toneladas".

Iluminuras, Porto Alegre, v. 21, n. 54, p. 527-568, setembro, 2020. 
Imagens 15; 16:
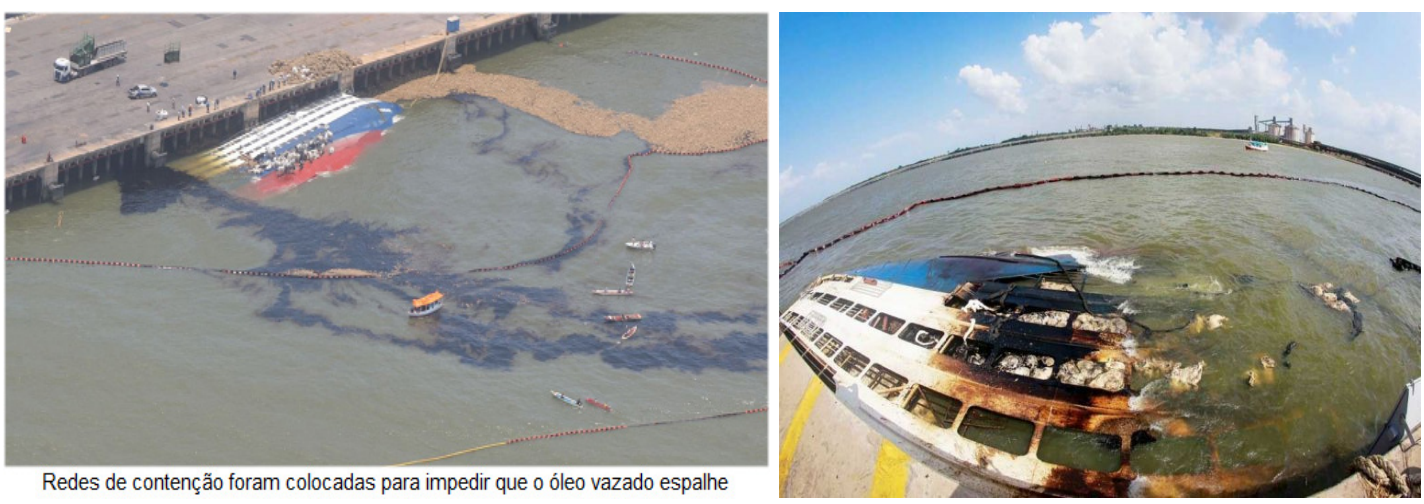

$\mathrm{Na}$ ocasião do desastre como mencionado acima, os bovinos que conseguiram se livrar das estruturas de aço do navio foram arrastados pelas águas, sendo que muitos animais diante do volume hídrico se afogaram. A partir daí as carcaças se dispersaram pelas praias próximas ao porto, onde seus corpos apodreceram durante dias nas paisagens ribeirinhas junto às vilas e habitações das comunidades locais - restando como o subproduto, ou o resíduo orgânico sólido das ações irresponsáveis em relação à vida, impetradas pelo mercado da carne na Amazônia. Além disso, havia a presença de cerca de 700 mil litros de óleo que vazaram da embarcação e se dispersaram por uma vasta área - o resíduo líquido que contaminaria ainda mais as águas do município deixando o cotidiano de muitas pessoas insuportável diante da mescla fétida de odores de carne putrefata e óleo, causando um dos piores desastres socioambientais do estado do Pará na atualidade.

Imagem 17:

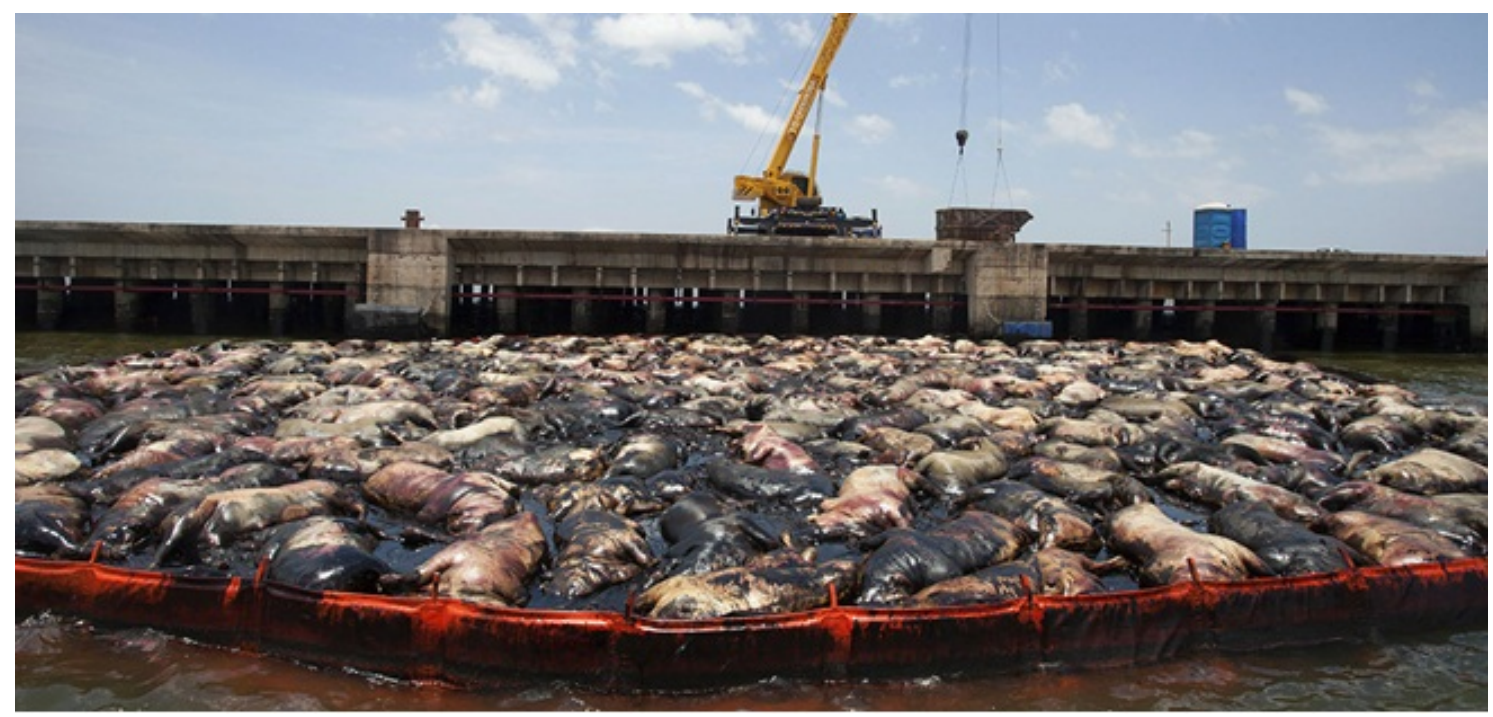


Os corpos mortos e inchados dos bois que se misturavam com o óleo vazado do imenso navio naufragado compunham as paisagens de horror no píer do porto de Vila do Conde, maculando as paisagens com os resíduos de suas ações naquele contexto. A postura da empresa responsável pelo navio foi a de divulgar uma nota dizendo que ninguém tinha se machucado no incidente. Expressava alívio por nenhum ser humano ter morrido, mas ignorava completamente o sofrimento dos bovinos. Os animais não foram tratados como seres vivos sencientes, mas como simples objetos a serem comercializados, mercadorias vivas capazes de serem abatidas, ou ainda, como propriedades que foram perdidas e contabilizadas como prejuízo para a empresa. Neste sentido, o termo técnico "carga viva" deixa bem evidente como seres vivos são objetificados e sua existência reduzida a mera matéria-prima capaz de engendrar pela ação humana, commodities a serem comercializados no mercado externo voltado ao consumo de carne e seus derivados, onde a alteridade animal não é considerada.

Mas a tragédia não causou sofrimento apenas aos bichos. Os milhares de bovinos que morreram afogados presos no navio, ou tentando nadar para se salvarem apodreceram no curso hídrico, ou as suas margens. A isto se somou a grande quantidade de óleo que vazou no ambiente. Ambos provocaram um dos maiores desastres socioambientais da história do estado do Pará, que afetaram diretamente a vida de milhares de pessoas e do próprio município: as carcaças dos bovinos, o odor putrefato e o óleo se espalharam pelas praias de Barcarena e pelos rios adjacentes.
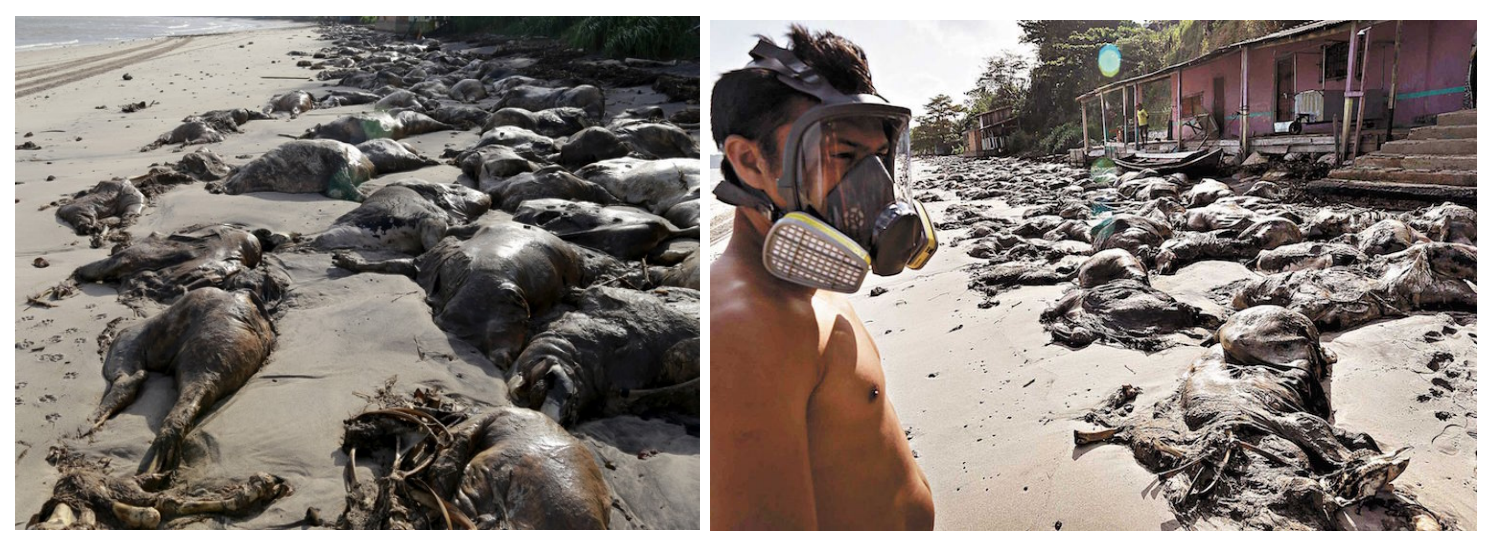
O que parece ser uma falta de sensibilidade diante do sofrimento e dor dos Outros $^{35}$ não humanos que morreram afogados no naufrágio do navio Haidar, contrasta profundamente com a sensibilidade estimulada pelo evento CowParade em relação às vacas de fibra de vidro, que foram expostas em vários lugares de Belém, quando o evento internacional se realizou nesta cidade. Aqui, temos um contraste entre as formas informes putrefatas dos existentes em Barcarena, e àquelas estetizadas dos animais de fibra de vidro como criações de arte no mundo urbano de Belém para regozijo das camadas médias e altas. Na Vila do Conde "o acontecido do boi", como nos disse uma senhora reverberava na memória dos moradores, a partir das imagens terrificantes de “acordar" certa manhã e se deparar com animais mortos na praia, que inchados e fétidos foram "espocando" e gerando um cenário grotesco aos moradores da matéria orgânica eviscerada se degradando, que se desdobrou em carência econômica e alimentar já que a pesca foi afetada e os turistas abandonaram a região considerada uma importante área de lazer e turismo, impedindo ainda a captura de peixes e fazendo os comerciantes sucumbirem em dívidas, uma vez que os produtos destinados à venda aos turistas não tinham mais saída.

\section{A arte conceitual: para além da fetichização burguesa da vaquinha à vaca podre e crua}

Faz pouco mais de cem anos desde que o artista francês Marcel Duchamp - com o pseudônimo de R. Mutt - enviou um urinol de louça, do tipo utilizado em sanitários masculinos como obra de arte intitulada "Fonte" para ser exposta no Salão da Associação de Artistas Independentes, em uma galeria de arte nos Estados Unidos. Com esta atitude Duchamp ampliou o conceito de arte e provocou uma profunda reflexão sobre a sua função e lugar político no mundo moderno.

${ }^{35}$ A referência a Susan Sontag (2003) é direta. 
Imagem 20:

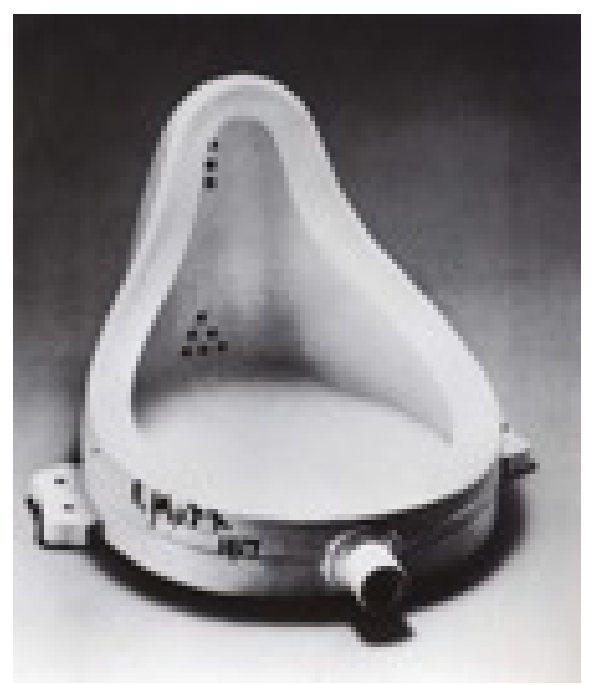

Fonte, 1917/64, porcelana, altura 33,5 cm, Marcel Duchamp, Indiana University Art Museum (Eskenazi Museum of Art), Bloomington. Edição de réplica autorizada de 1964 (original de 1917).

Sua contribuição para o amadurecimento da arte conceitual que deveria possuir um viés de questionamento da realidade, e não apenas de simples contemplação, toma o observador de uma obra não mais como um expectador passivo, já que figura como alguém que reflete e interage com ela e, ao fazê-lo, a (re)criaria sensivelmente a partir de seu universo de informações e gostos pessoais, bem como pela movência de imagens numa paisagem que implica entender o observador e a obra como conexos num devir ético-estético para além da mera contemplação. Ao invés da ideia de belo que domina as chamadas "belas artes", na arte conceitual a obra se apresenta como estopim para devaneios e reflexões mais ou menos tensionais, abrindo-se às contradições e paradoxos. Nestes termos, o artista propõe questionamentos e amplia as possibilidades da arte como linguagem e, sendo assim, tem uma atitude específica diante das formas que evoca.

É por isso que ao pixar a palavra NAUFRÁGIO na vaca-simulacro idealizada pelo artista da CowParade, ao questionar afã pop de produção em série e às ideologias da campanha - etnicizada em alguns casos, folclorizada noutros, reificando construções identitárias - a artista interagiu criticamente com a obra exposta na rua e ampliou suas ressonâncias na urbe amazônica, evocando a vaca escatológica podre na praia (aqui o urinol vibra) na "vaquinha" kitsch no bairro nobre da Cidade das Mangueiras. Longe de qualquer atitude passiva ela revelou agências (resignificadoras/transfiguradoras) que se somam às do artista. Ela potencializou as suas imagens primeiras trazendo-as para o 
campo de uma ecologia social ${ }^{36}$, de crítica às formas pelas quais a vida é tratada em alguns contextos amazônicos, tanto pelo que perece quanto pelo que convive com a sua putrefação. As artes sejam elas quais forem nesse jogo se entrechocam, se coadunam, se multiplicam no mundo urbano belenense como dimensões ético-estéticas e políticas da existência precária do vivo na Amazônia. A artista não pixou a vaca a esmo. Não havia intenção de destruir a obra, ou simplesmente de desfigurá-la. Ela tinha um questionamento contundente para fazer sobre o que se experimentava à época como dimensão trágica do vivido, e assim o fez.

Não é nossa intenção julgar se a intervenção sobre a obra é ou não um ato criminoso, deixamos a cargo dos juízes ${ }^{37}$ a questão. Interessa-nos certa leitura acerca dos significados da ação que instauram outras dimensões ético-estéticas e políticas, e o que está por trás das interpretações depreciativas questionáveis que foram feitas sobre o episódio, quando nos parece que a artista quis protestar contra o silêncio de um crime socioambiental de grandes proporções nas paisagens ribeirinhas amazônicas.

A vaquinha prateada figurava agora como uma imagem direta da morte desfigurada, no intenso sofrimento de milhares de bovinos de carne e osso que afetou coletivos humanos que vivem na região e seu ambiente próximo: o contexto de uma exposição como a CowParade, que usa justamente corpos de vacas como telas para arte era, a partir de sua agência, a evocação crítica de uma catástrofe que ocorrera não muito longe dali e que deixara seus rastros na forma de lixo orgânico apodrecendo a céu aberto. O prata da vaca e o laranja do spray, como evocado antes, vibravam noutro problema socioambiental vergonhoso no contexto paraense.

O pixo fez convergir imagens potentes em torno das figurações bovinas, das ambíguas intervenções humanas nos lugares, ligando diretamente as vacas de fibra de vidro àqueles bovinos de carne e osso que sucumbiram. Vacas de fibra de vidro não se machucam, não morrem, mas podem lembrar a tragédia recente, o sofrimento de

\footnotetext{
${ }^{36}$ Ecologia social é um conceito criado pelo geógrafo anarquista Elisée Reclus em fins do século XIX e reapropriado pelo filósofo anarquista Murray Bookchin nos anos de 1960. Sustenta a ideia que os problemas ecológicos atuais estão arraigados e profundamente assentados em problemas sociais, particularmente no domínio dos sistemas políticos e sociais hierarquizados. Estes resultaram de uma aceitação não-crítica de uma filosofia hipercompetitiva do crescer ou morrer. Sugere também que não é possível fazer frente a tais problemas através de ações individuais como o consumismo ético, mas precisa estar relacionado a formas de pensamento éticos mais profundas e atividades coletivas fundamentadas em ideais democráticos radicais (libertários). A complexidade das relações entre pessoas e a natureza é enfatizada, junto com a importância de se estabelecer estruturas sociais que possam levar em conta tais relações. (ver: https://pt.wikipedia.org/wiki/Ecologia_social)

${ }^{37}$ A ironia é que no Brasil a pichação é considerada um crime contra o ambiente, nos termos do artigo 65 da Lei 9.605-98, Lei dos Crimes Ambientais. A pichação, por sua vez, sendo "considerada um crime contra o ambiente" é utilizada pela artista justamente para denunciar um crime ambiental de grandes proporções, um verdadeiro desastre ambiental vivido em terras paraenses.
} 
milhares de bois que ainda apodreciam no fundo das águas do porto de Barcarena. A vaca do deleite estético era a mesma que apontava para a falta de ética para com seus congêneres, bem como em relação aos ecossistemas locais, onde pessoas e coletivos não-humanos diversos constituem as paisagens praticadas no contexto de Barcarena.

Ora, o naufrágio envolvendo bois de carne e osso e suas consequências e a exposição a céu aberto das vacas de fibra de vidro foram relativamente contemporâneos, os efeitos causados pelo naufrágio em termos de degradação socioambiental desdobraram-se em situações nefastas para as populações humanas e ecossistemas regionais, a podridão que empestava narizes e o verdadeiro banquete de urubus ainda estava vivo no imaginário associado ao tempo de penúria e fome, como nos disseram quando visitamos a Vila do Conde no segundo semestre de 2018, as memórias do naufrágio ainda vibravam nas paisagens praticadas pelas pessoas, enfim, as suas imagens eram bem recentes quando as vacas coloridas da CowParade começaram a aparecer em Belém, em 20 de agosto de 2016. Tanto que ainda no dia 6 de abril de 2016 a reportagem do G1 Pará, ligado ao sistema Globo de comunicação de quem a TV Liberal é afiliada, anunciava que "[a]pós 6 meses de Naufrágio, navio e bois ainda estão submersos no PA, empresas recorreram de ação judicial e ainda não pagaram indenizações, população denuncia contaminação da água e dos peixes ${ }^{38}$ ". O navio, como lixo industrial, permanecia submerso no rio Pará.

Portanto, menos de cinco meses antes do início da CowParade Belém 400 anos, os corpos apodrecidos dos bovinos de carne e osso, bem como, o navio continuavam afundados no porto de Vila do Conde, e as pessoas afetadas pela tragédia ainda não tinham sido assistidas pela empresa que seguia recorrendo de decisões judiciais enquanto alguns festejavam "as vaquinhas". Apesar da proximidade destes dois eventos envolvendo "bovinos", nenhuma das 50 vacas pintadas para a CowParade Belém 400 anos fizeram qualquer referência ou menção ao naufrágio, fato tão recente ligado às imagens de corpos bovinos que circularam na mídia local e nacional, justamente os corpos que na CowParade serviam como telas tridimensionais oferecidas aos artistas amazônidas. Em outras palavras, as mortes e o sofrimento de milhares de bovinos passaram em branco - assim como a penúria dos coletivos humanos - invisibilizados, justo em um evento que utiliza esculturas de corpos bovinos como telas para criação de obras de arte que evocam a cultura daquela gente aviltada, e que em tese, buscam estimular respeito e empatia das pessoas por estes animais e a cultura paraense.

\footnotetext{
${ }^{38}$ Fonte G1 Pará - http://g1.globo.com/pa/para/noticia/2016/04/apos-6-meses-de-naufragio-navio-e-boisainda-estao-submersos-no-pa.html
} 
A ação da artista foi filmada por uma pessoa que passava em um carro no exato momento de sua intervenção. Segundo Métis, que "soube pela televisão" que o seu ato de pixação havia sido filmado por alguém que enviara a um jornal local, foi motivo de surpresa, pois "a gente deu a sorte que filmaram". Elas sabiam que alguém vira a pixação, pois teriam gritado: "ô filha da puta, não sei o quê, tá escrevendo na obra de artista". Ela considera que tiveram "muita sorte porque era nos finais, a palavra já estava completamente escrita", e ressalta que "a gente imaginava isso, vai pixá, vão apagá e vai ficar por isso mesmo, né!"

A filmagem foi, então, enviada e exibida no dia 8 de setembro de 2016 no telejornal local do grupo O Liberal, chamado Bom Dia Pará. Ao apresentarem o vídeo, os ancoras do telejornal jornal assim se expressaram sobre o episódio:

\begin{abstract}
- Olha nós recebemos um vídeo que mostra uma mulher (ênfase) pichando uma das vacas da exposição CowParade, que está sendo realizada aqui em Belém. Como você pode ver (vídeo sendo exibido) uma cena lamentável! Um ato criminoso! Que não deveria acontecer.

- E a gente lamenta muito ter que mostrar esse tipo de atitude de uma pessoa que não representa, é claro, a opinião do povo paraense sobre essa exposição! Uma exposição mundial muito famosa. Nós procuramos a organização do evento que lamentou esse fato e disse que foi um caso completamente isolado, e que a vaquinha já foi reparada imediatamente pela equipe de apoio da organização.

- Infelizmente, atos de pessoas assim mancham completamente a imagem da nossa cidade e da população paraense, né? Por isso a gente aqui do Bom Dia Pará espera que fatos isolados como este não se repitam! (Fonte: G1 Pará, colido em http://g1.globo.com/pa/para/noticia/2016/09/video-mostra-mulher-pichando-vacada-exposicao-cow-parade-em-belem.html) (grifo nosso).
\end{abstract}

Na apresentação do telejornal a intervenção - o pixo na vaca - é completamente destituída de seu contexto social, político e ecológico - ou, ainda, de uma ecologia social e política - nem sequer uma referência ao naufrágio ocorrido no município de Barcarena é realizada pelos apresentadores, nenhuma menção à tragédia envolvendo o navio Haidar. Reina um silêncio cúmplice com o morticínio e com a pestilência experimentados em Barcarena. Fulgura certa imagem da arte, de percepção equivocada sobre o seu lugar sócio-político no mundo urbano, destituída de crítica, imersa num esteticismo per se ela reifica uma visão da arte pela arte e esgota sua potência reflexiva no mundo urbano belenense enquanto as vacas apodrecem. O pixo "mancha", macula, a obra e produz o incômodo diante da "arte legítima" - ao mesmo tempo que reverbera na mancha de óleo que macula as paisagens de humanos e não humanos: trata-se, neste caso, de uma arte menor, de rua, um lixo estético para os amantes do belo.

Métis mencionou ter ficado "chateada pela repercussão que teve porque as pessoas não relembraram necessariamente do episódio, do que aconteceu". Para ela, a 
discussão "se pixação era arte ou não era", revelou-se uma questão menor já que "não era isso que me interessava discutir... era a omissão da sociedade frente a um crime e que pessoas continuavam morrendo por conta dele, né".

Além disso, não se trata da artista "não gostar da obra", como sugeriu o autor da "vaquinha" intitulada "Noites Brancas" na mesma matéria que denunciam o "crime", mas de um diálogo criativo que seria próprio a uma estética urbana que funda uma ética de relação entre lugares na Amazônia paraense, e que denuncia certo distanciamento da capital em relação àquilo que não seja regozijo seu para consumo identitário, seu deleite e emulação, como no caso da "Vaca Açaizera" ou da "Vakaiapó". E mais, seria uma percepção sensível oriunda da expressão do feminino na arte de rua, o que nos coloca uma questão de gênero evidente, quiçá urgente, para a reflexão sobre o lugar da inteligência criadora da mulher na Amazônia brasileira.

Mas há um paradoxo interessante aí. Ao negarem-se a uma reflexão sobre as significações daquela pixação, divulgam-na e, de maneira enviesada, a imagem da intervenção urbana assume proporções ampliadas pela redundância da denúncia - a vaca simulacro se reduplica, se esgarça prateada ou putrefata - atinge de muitas formas as pessoas que compreendem do que se trata, das mazelas do naufrágio dos bichos e de uma ideia hegemônica de arte contemporânea (canonizada até quando figura nas esquinas) que se esboroa diante a crítica de pessoas que circulam nas ruas. O certo é que a vaca se de-sacraliza no comezinho da estagnação, no fedor da noite branca que deitam luzes sobre corpos inchados, ribeirinhos.

O jornal, como de costume, se resumiu a fazer uma condenação pública do ato: “é um ato lamentável”, "que não deveria mais acontecer”, pois “esse tipo de atitude não representa a opinião do povo paraense sobre essa exposição" - como se isso fosse sondável, como se fosse possível uma afirmação generalista sobre um tema tão complexo ligado a uma visão homogênea de "povo paraense", por si só complexo e heterogêneo nas suas figurações regionais. Daí afirmarem que "atos de pessoas assim mancham completamente a imagem da nossa cidade e da população paraense", quando deveriam mencionar a mancha pútrida-oleosa que agride o olhar em Barcarena. Certamente, as pessoas afetadas pelo problema nesta cidade não foram consultadas sobre isto - qual seria a sua opinião? - as afirmações contundentes feitas pelos ancoras do jornal demonstram bem ao que servem as vacas totêmicas da arte em relação às vacas-produto a caminho de matadouros da globalização econômica, não raro, irresponsável à vida no contexto urbano paraense, quanto mais aos longes. 
A organização do evento CowParade seguiu a mesma linha de raciocínio limitante, perdendo a oportunidade de estabelecer um rico debate sobre certas questões ligadas ao caráter político da arte no mundo urbano amazônico. Nenhuma reflexão sobre o significado artístico do pixo no horizonte hermenêutico das obras inseridas nas ruas, apenas lamentaram o ocorrido e afirmaram que a "vaquinha" já tinha sido "reparada" pela equipe de apoio, já que teria sido aviltada, maculada, pelo ato da jovem mulher. O pixo na vaca da CowParade foi noticiado nacionalmente, e no Pará, se reproduziram interpretações de que a intervenção - o pixo - era:

1. Uma ação que nada tinha de artística - daí presumir-se que seria uma espécie de lixo estético - e, desta forma, achatava a experiência estética urbana a certa visão de arte menor, ressecando a sua potência ética e reflexiva;

2. Um ato de desrespeito e vandalismo sobre a coisa pública ou imaculada da arte, quando era necessário pensar as agências pessoais no mundo urbano, como formas de apropriação criativa da arte pela ressignificação formal de seus conteúdos, porque contextualizados naquilo que seria terrificante, quiçá infecto.

Estas interpretações ainda que não tenham sido unânimes foram hegemônicas, e se reproduziram difusamente pela internet ao sabor das tensões diversas, nas posições no debate de acordo com pontos de vista distintos sobre o dilema. De fato, os bois de carne e osso que morreram afogados parecem não ter suscitado a mesma empatia que as "vaquinhas" da CowParade. Entre o grotesco e o mimoso das vacas, a figura fugidia da pixadora se desloca como potência do feminino, como figuração do humano em mais uma catástrofe no Capitaloceno (Moore, 2016).

$\mathrm{O}$ dilema das coisas e de suas agências aqui toma sentidos plurais no contexto urbano, vivificando as fronteiras entre puro e impuro (Douglas, 1976; Serres, 2011). As objetificações dos existentes vivos são distintas daquelas de fibra de vidro: os bois de carne e osso foram tratados como objetos de consumo para boiarem de-sacralizados a sua mortificação, e inchados explodirem num espetáculo macabro e fétido. As vacas de fibra de vidro como seres-vaquinhas-iluminados, ou coloridos, são merecedoras de respeito pela aura que lhes concederam, pela estética quente de suas imagens em oposição ao eviscerar grotesco e putrefato numa paisagem de desolação. Acontece que ambos, bois de carne e osso e vacas de fibra de vidro são encarados como propriedades privadas: mercadorias, a carga viva de um lado, e o objeto de arte de outro.

Ao fazer referência direta a um acontecimento que ainda estava presente na vida dos habitantes da metrópole, portanto, vibrando no imaginário como figurações recentes de uma "cultura do terror" (Taussig, 1993) em plena globalização do vivo como objeto 
imolável na Amazônia, a jovem mulher ligava a cena das vacas coloridas de Belém à dor e sofrimento dos bois mortos no naufrágio - e que restavam descarnados e fétidos ao sofrimento das pessoas que ainda sentiam os efeitos desta tragédia em Barcarena, sua miserabilidade extrema. Neste sentido, as artistas criaram outra obra, transfiguraram-na criticamente, pois as suas escolhas e ações criadoras não foram por acaso, as artistas tinham justamente esta intenção ao usá-la como tela.

Mas o que fica evidente neste quadro paradoxal que pintamos, que mescla tintas de insensibilidade e horror, é que se faz necessário chamar a atenção para alguns fatos relacionados ao CowParade Belém 400 anos, especialmente quando consideramos a grandiosidade dos impactos socioambientais causados em toda a região pelo naufrágio em questão: a indiferença com que os organizadores e participantes do CowParade Belém 400 anos trataram a tragédia do naufrágio do Haidar, que aconteceu pouco tempo antes do início da chegada das "vaquinhas coloridas" na cidade de Belém; e a reação do jornal $O$ Liberal e dos organizadores do CowParade Belém 400 anos contra a pixação feita pela artista de Belém, que conectou irremediavelmente a exposição de arte à exposição de horrores resultante do naufrágio.

\section{Considerações Finais}

A ação do pixo se afirma como uma intervenção artística autônoma e livre feita no contexto de uma exposição de arte na rua, originando uma outra obra de arte que passou a dialogar com eventos de grande impacto social e ambiental na região, associado à presença de resíduos químicos e orgânicos nas paisagens. Desta forma, a intervenção artística por meio do pixo alargou tanto as fronteiras das possibilidades de interação com a exposição de arte, como criou uma obra coletiva de caráter efêmero diante do exercício de poder em eliminá-la em prol do "bom gosto", atribuindo ao pixo o caráter maculador de produção de "manchas" que afetariam a imagem da cidade e do "povo paraense".

Quando a artista pixou a obra ela não jogou apenas tinta sobre o bovino sintético, não atingiu apenas o corpo de fibra de vidro da vaca, ela mexeu com as estruturas que constituem a sociedade capitalista desigual e autoritária no contexto amazônico, fundamentada na propriedade privada de corpos não humanos: cutucou simbolicamente as vísceras podres das vacas mortas. Quando a artista pixou a "vaquinha" ela botou as entranhas da sociedade para fora, mexeu com um dos pilares dessa sociedade que é justamente a propriedade privada e sua adoração pelo belo, às vezes, duvidoso. 
Este é um dos elementos que mais assustam e que mais causam reações contra a pixação e a street art - ainda mais quando produzidas por mulheres - enquanto o grafite pode ser interpretado como arte e usado para a valorização da propriedade, o pixo parece sempre afrontar a propriedade e o conceito tradicional de arte como "belas artes", como o permitido e o viável no mundo urbano planejado.

A pixação é comumente interpretada como uma ameaça a propriedade, e por isso grande parte da população sente empatia pelo proprietário e ojeriza em relação ao pixador, a interpretação corrente é a de que ela representa uma ameaça não só àquele que teve sua propriedade pixada, mas uma ameaça a todos, à propriedade de todos e isso acaba mexendo com os valores das pessoas, fazendo com que se crie um permanente estado de marginalidade para esta arte e para os artistas que a praticam, justamente porque eles intervêm (e maculam, tornam impuro) em algo que é apresentado pelo senso comum capitalista como tabu, como sagrado, cuja defesa estaria na natureza humana: a propriedade privada.

Quando a jovem pixou a palavra "naufrágio" no corpo da vaca trouxe de volta a memória da dor e sofrimento de milhares de bois que morreram afogados por meio de um protesto que a exposição CowParade nem cogitou. Ao mexer com a sensibilidade das pessoas, ao pixar a "vaquinha" de fibra de vidro da CowParade, a artista também evidenciou a insensibilidade com a qual os bois vivos foram tratados diante de um morticínio ecocida, quando não foram lembrados por nenhum artista na exposição e, obviamente, muito menos a população ribeirinha afetada pelo desastre socioambiental com os resíduos do evento. Portanto, ao pixar a "vaquinha" a artista trouxe novamente o debate sobre as sensibilidades em relação aos humanos e aos não humanos na Amazônia com o qual nos alinhamos, evidenciando o quanto às vezes determinados elementos podem mobilizar mais empatias e sentimentos do que seres vivos sencientes congêneres ou não, o pixo mais uma vez confrontou a propriedade privada em nome da arte e do protesto no mundo urbano. A vaca pixada foi repintada pela organização da CowParade para ser vendida no leilão, mas a obra coletiva e provocadora produzida pela intervenção artística continua nas ruas, nas fotografias e nas potências do imaginário que vibram na metrópole amazônica, ainda que uns não queiram.

\section{REFERÊNCIAS}


ACEVEDO MARIN, Rosa Elizabeth. Quilombolas-indígenas do Sitio João: formas de existência e resistência no Rio Murucupi, Barcarena/ Rosa Elizabeth Acevedo Marin; Rosane de Oliveira Martins Maia. - 2014.

ADAMS, C. J. A política sexual da carne. A relação entre carnivorismo e a dominância masculina. São Paulo: Ed, Alaúde, 2012.

Agencia IBGE de notícias, 29-09-2017. colido em 25-09-2018 no Site: https://agenciadenoticias.ibge.gov.br/agencia-noticias/2012-agencia-denoticias/noticias/16994-rebanho-de-bovinos-tem-maior-expansao-da-serie-historica.

BACHELARD, G. A Poética do Espaço. São Paulo: Martins Fontes, 1988.

BALÉE, W. Cultural Forests of the Amazon: A Historical Ecology of People and Their Landscapes. University of Alabama Press, 2013.

BAUDRILLARD, J. “Modernité”. In: Encyclopaedia Universalis. Paris.12: 424-26, 1985.

BELLO, E. A teoria política da propriedade na era moderna: ascensão e crítica do individualismo possessivo. Quaestio Iuris, vol. 05, no 01. p. 220-241. Ano 2012

BELTRÃO, J. F.; RODRIGUES, C. I. Quando o sabor da ribeira aponta a instituição de identidade(s) em espaço urbano. In: TRINDADE Jr, S-C. C.; SILVA, M. A. P. da. (Orgs.). Belém. A cidade e o rio na Amazônia. Belém: ADUFPA, 2005, pp. 44-62.

BOURDIEU, Pierre. "Gostos de classe e estilos de vida". In: Renato Ortiz (org.). Pierre Bourdieu - Sociologia. São Paulo: Ática, 1983.

CERTEAU, M. de. A Invenção do Cotidiano. Artes de fazer. V. 1. Rio de Janeiro: Vozes, 1994.

CLOAREC, J. Le paysage “catastrophe”. Symboles et réalites. Ethnologie Française, CNRS/Réunion des Musées nationaux, 3(19): 299-303, 1989.

CROSBY, A. W. Imperialismo Ecológico. A expansão biológica da Europa: 900-1900. São Paulo: Companhia das Letras, 1993.

DIÓGENES, G.; CHAGAS, J. O ruidoso silêncio da pixação: linguagens e artes de rua. Revista do Programa de Pós-Graduação em Artes, Cultura e Linguagens Instituto de Artes e Design. 2(1): 304=330, 2016.

DIÓGENES, G.; CAMPOS, R.; ECKERT, C. As cidades e as artes de rua: olhares, linhas, texturas, cores e formas (apresentação). Revista de Ciências Sociais, Fortaleza, 
1(47): 11-24, 2016.

DOUGLAS, M. Pureza e Perigo. São Paulo: Perspectiva, 1976.

DUCHAMP, M. In Infopédia [Em linha]. Porto: Porto Editora, 2003-2011. [Consult. 2011-03-12]. Disponível na www: <URL: http://www.infopedia.pt/\$marcel-duchamp>.

HEIDEGGER, M. Ser e tempo. Trad. Márcia de Sá Cavalcante. Parte I. Petrópolis: Vozes, 1993.

LEAL, L. M. "Com o spray na mão pintando um muro e não em casa pintando as unhas": um estudo sobre grafiteiras nas paisagens urbanas de Belém do Pará. Trabalho de Conclusão de Curso em Ciências Sociais, Belém: UFPA, 2019.

MONTEIRO, M. de A.; MONTEIRO, E. F. Amazônia: os (des) caminhos da cadeia produtiva do alumínio. Novos Cadernos - NAEA, 2(10): 87-102, 2007.

MOORE, J. W. (Ed.). Anthropocene or Capitalocene? Nature, History, and the Crisis of Capitalism. Oakland: Kairos Books, 2016.

PAIXÃO, S. J. C. da. O meio é a paisagem: pixação e grafite como intervenções em São Paulo. São Paulo, 2011.

PEDROSA NETO, C.; SILVEIRA, F. L. A. da. A tragédia de Barcarena (PA): a água envenenada e a resistência ribeirinha. Fotocronografias, Porto Alegre, 2018. https://medium.com/fotocronografias/a-trag\%C3\%A9dia-de-barcarena-pa-a$\% \mathrm{C} 3 \%$ A1 gua-envenenada-e-a-resist\%C3\%AAncia-ribeirinha-1-6e33756518f5 PEREIRA, A. B. As marcas da cidade: a dinâmica da pixação em São Paulo. Lua Nova, São Paulo, 79: 143-162, 2010.

PINHEIRO, L. Rizoma-pixo, devir-rato. Concinnitas, 19(2): 139-145, 2011.

POZZOBON, T. CowParade Porto Alegre 2011: mercado e representações. Artigo apresentado no III Encontro Nacional de Estudos da Imagem 03 a 06 de maio de 2011 Londrina - PR.

. As relações entre arte contemporânea e marketing cultural: Cowparede Porto Alegre 2010. Dissertação apresentada ao programa de Pós-graduação em Artes Visuais, UFSM/RS, Santa Maria, 2012.

RAPPOPORT, E. H. Descubrimiento de América: el punto de vista ecológico y biogeográfico. Ciência \& Ambiente. Santa Maria/UFSM; Ijuí:UNIJUÍ, 3(5): 41-63, 1992. 
RICOEUR, P. Interpretação e ideologias. Organização, tradução e apresentação de Hilton Japiassu. Rio de Janeiro: Francisco Alves, 1990.

RIVERO, S.; ALMEIDA, O.; ÁVILA, S.; OLIVEIRA, W.. Pecuária e desmatamento: uma análise das principais causas diretas do desmatamento na Amazônia. Nova Economia_Belo Horizonte_19 (1)_41-66_janeiro-abril de 2009. (Este artigo contou com o financiamento do $C N P q$ nos projetos $M C T / C N P q / P P G 7$ - 048/2005 e edital CNPq “casadinho” - Edital CNPq 07/2006 (processo 620235/2006-3). Artigo recebido em dezembro de 2008; aprovado em maio de 2009.

SILVEIRA, F. L. A. da. As paisagens fantásticas e o barroquismo das imagens. Estudo da memória coletiva de contadores de causos da região missioneira do Rio Grande do Sul. Tese de Doutorado, UFRGS, Porto Alegre, 2004.

SERENO, A. O ready-made em Marcel Duchamp, a dimensão estética e o seu caráter conceptual na contemporaneidade, Porto, 2010.

SERRES, M. O mal limpo. Poluir para se apropriar? Rio de Janeiro: Bertrand Brasil, 2011.

SHAPIRO, R. Que é artificação? Sociedade e Estado, Brasília, 1(22):135-151, 2007.

SONTAG, S. Diante da dor dos outros. São Paulo: Companhia das Letras, 2003.

TAUSSIG, M. Xamanismo, colonialismo e o homem selvagem. Um estudo sobre o terror e a cura. Rio de Janeiro: Paz e Terra, 1993.

VANDER VELDEN, F. Inveja do gado: o fazendeiro como figura de poder e desejo entre os Karitiana. Anuário Antropológico, 1: 55-76, 2011.

Lista de Referencias de Imagens:

Imagem 1: Fonte: № 40 Galeria das Vacas - Realizador: Shop. Grão Pará Artista: Rhodrigo Maia Obra: Vaca Açaizeira Endereço: Shopping Bosque Grão Pará, Av. Centenário, 1052 - Val-De-Cans Fonte: http://www.cowparade.com.br/pa/

Imagem 2: Fonte: № 38 Galeria das Vacas - Realizador: Extrafarma Artista: Patrick Sandre Obra:Vakayapó Endereço:Icoaraci - Orla, Rua Siqueira Mendes, Próx. à Feira do Artesanato do Paracuri. Fonte: http://www.cowparade.com.br/pa/ 
Imagem 3: Fonte: № 21 Galeria das Vacas - Realizador: Extrafarma Artista: Jocatos Obra: Noites Brancas Endereço: Codem Tribunal, Av Nazaré, Esquina com Tv Quintino Bocaiuva.

Imagem 4: Hiperlink para video do momento da pixação.

Imagem 5: Colida em 09/09/2019 do site: Etetuba - arte e resistência cultural: https://etetuba.blogspot.com/2016/09/arte-e-lugar-de-protesto-alguns-dados.html

Imagem 6: Hiperlink para video do momentodo Naufrágio.

Imagem 7: Hiperlink para video da reportagem 6 meses após o naugrágio.

Imagem 8: : Hiperlink para video da reportagem 2 anos após o naugrágio.

Imagem 9: Fonte: Imagem colida em 09/09/2019 do sitio: "Jornal Pelicano" (Foto: Renato Pereiral Arquivo pessoal), endereço eletrônico: https://www.jornalpelicano.com.br/2015/10/embarcacao-com-5000-bois-aderna-eafunda-no-para/

Imagem 10: Fonte: Imagem colida em 09/09/2019 do sitio: "Rural book", endereço eletrônico: http://ruralbook.com.br/navio-aproximadamente-5000-bois-afunda-em-vilaconde/

Imagem 11: Fonte: Imagem colida em 09/09/2019 do sitio: "Parcifal 5.8", endereço eletrônico: http://pjpontes.blogspot.com/2015/10/a-tragedia-do-haidar.html 
Imagem 12: Fonte: Imagem colida em 09/09/2019 do sitio: "Rural book", endereço eletrônico: http://ruralbook.com.br/navio-aproximadamente-5000-bois-afunda-em-vilaconde/

Imagem 13: Fonte: Imagem colida em 09/09/2019 do sitio: "Parcifal 5.8", endereço eletrônico: http://pjpontes.blogspot.com/2015/10/a-tragedia-do-haidar.html

Imagem 14: Fonte: Imagem colida em 09/09/2019 do sitio: "UOL" (Fonte: Ascom/Adepará), endereço eletrônico: https://canalrural.uol.com.br/noticias/secretariapara-recebe-plano-acao-para-porto-barcarena-59745/

Imagem 15: Fonte: Imagem colida em 09/09/2019 do sitio: "Parcifal 5.8", endereço eletrônico: http://pjpontes.blogspot.com/2015/10/a-tragedia-do-haidar.html

Imagem 16: Fonte: Imagem colida em 09/09/2019 do sitio: Cut Pará, endereço eletrônico: https://pa.cut.org.br/noticias/empresas-terao-15-dias-para-retirar-naviohaidar-do-rio-80ef

Imagem 17: Fonte: Imagem colida em 09/09/2019 do sitio: "Direitos dos Animais", endereço eletrônico: http://direitosdosanimais.org/website/noticia/show.asp?pgpCode=99013A5D-3CE474DC-CBD8-682A6ABCA2A4

Imagens 18: Fonte: Imagem colida em 09/09/2019 do sitio: "Revista Veja", Centenas de animais mortos são levados pelo rio Pará até a praia de Vila do Conde, onde ficam encalhados na areia, parte do gado já foi retirado da praia, que está interditada. Um navio de bandeira libanesa Haidar tombou na terça-feira (6) no cais do porto de Vila do Conde, em Barcarena, nordeste do Pará (VEJA.com/Reuters). Endereço eletrônico: https://veja.abril.com.br/brasil/desafio-no-para-como-tirar-4-600-bois-do-fundo-do-rio/ 
Imagem 19: Fonte: Imagem colida em 09/09/2019 do sitio: "Carajas tudo de bom", (foto Tarso Sarraf, $\quad O \quad$ Liberal), endereço eletrônico:http://www.carajastudodebom.com.br/noticia/para/001268760/cdp-nao-templano-para-resgate-de-bois-em-barcarena

Imagem 20: Colido em 30/07/2019, fonte site: https://www.historiadasartes.com/salados-professores/fonte-marcel-duchamp/

Sites relevantes:

Critica a Cowparade

http://laborativo.blogspot.com/2012/09/banksy-vs-cow-parade-os-limites-da-arte.html http://paulofontelesfilho.blogspot.com/2016/09/claudio-carvalho-cow-paradeestrategia.html

História da CowParade https://brasiledesenvolvimento.wordpress.com/2012/02/18/historias-do-desfile-da-vaca/ Site oficial da CowParade Belém:

http://www.cowparade.com.br/pa/

Recebido: 03/06/2020

Aprovado: 04/09/2020 